\title{
An improved design for cellular manufacturing system associating scheduling decisions
}

\author{
R SUBHAA $^{1, *}, \mathrm{~N} \mathrm{JAWAHAR}^{2}$ and S G PONNAMBALAM ${ }^{3}$ \\ ${ }^{1}$ SSM Institute of Engineering and Technology, Dindigul 624 002, India \\ ${ }^{2}$ Ramco Institute of Technology, Rajapalayam 626 117, India \\ ${ }^{3}$ Faculty of Mechanical and Manufacturing Engineering, Universiti Malaysia Pahang, Pekan, Malaysia \\ e-mail: rsubhaa@yahoo.com; jawahartce@yahoo.co.uk; sgponnambalam@ump.edu.my
}

MS received 29 November 2018; revised 14 February 2019; accepted 14 April 2019; published online 4 June 2019

\begin{abstract}
This paper presents a model for the design of Cellular Manufacturing System (CMS) to evolve simultaneously structural design decisions of Cell Formation (CF) and operational issue decisions of optimal schedule. This integrated decision approach is important for designing a better performing cell. The model allows machine duplication and incorporates cross-flow for scheduling flexibility. The cross-flow is the term introduced to mean the inter-cell movement of parts from parent cell to identical machines in other cells though machines are available in the parent cell. This cross-flow facilitates routing flexibility and paves way for reduced schedule length thereby optimizing resources leading to minimized operational cost. A non-linear integer mathematical programming model is formulated with the objective function of minimizing operating cost which is the sum of Machine Utility Cost (MUC) and inter-cell costs. The MUC is a new cost parameter based on machine utility and it integrates $\mathrm{CF}$, scheduling, and machine duplication decisions. The proposed model belongs to the class of NP-hard problems. A hybrid heuristic (HH) that has "Simulated Annealing Algorithm (SAA) embedded with Genetic Algorithm (GA)" is proposed. A comparison with the mathematical solution reveals that the proposed $\mathrm{HH}$ is capable of providing solutions closer to optimal in a computationally efficient manner. The model is validated by studying the effect of integrated decisions, machine duplications, and association of scheduling and cross-flow. The model validation reveals that the proposed CMS model evolves $\mathrm{CF}$, scheduling, and machine duplication decisions with minimum operating cost. Thus, it can be inferred that the proposed model gives optimal integrated decisions for designing an effectively and efficiently performing cells and thus evolves improved CMS design decisions.
\end{abstract}

Keywords. Simulated annealing algorithm; genetic algorithm; scheduling; cellular manufacturing system; cell formation.

\section{Introduction}

The Cellular Manufacturing System (CMS) finds application in discrete parts manufacturing industries like automobiles, furniture, machine tools, smartphones, and airplanes manufacturers [1] where the variety of end items and subassemblies for different models are produced. The CMS and its implementation bring forth significant advantages in the quest for faster, better, cheaper production and delivery of manufactured products [2]. The primary concern of CMS is cell formation (CF) problem that has to identify the groups of parts forming part families and

Electronic supplementary material The online version of this article (https://doi.org/10.1007/s12046-019-1135-8) contains supplementary material, which is available to authorized users.

*For correspondence set of machines for each part family forming the machine cells. The CF decisions are generally made by optimizing the objectives of minimizing inter-cell $[3,4]$ and intra-cell movements, minimize throughput time, minimize total operation cost [5], maximize machine utilization, minimize cell load unbalances, etc. The review paper of Papaioannou and Wilson [6] indicated that most authors of the CF problem have worked on the attainment of cell independence with the performance measure as minimizing intercell movements or material handling costs. The other main consideration is minimizing the sum of machine duplication and inter-cell move costs [7].

But there is a need for CF problem to consider operational issues and related costs in an integrated way to address the actual manufacturing system and its requirements. The advantages of CMS are effectively realized by the integration of design, and production planning and control with their objectives being shared through a 
suitable field [8]. The review by Chattopadhay et al [9] mentioned that the research objectives by researchers focus mostly on the design issues of CMS with the major focus on CF problem whereas the control issues are least bothered and a good design can be evolved with improved production performance by an integrated approach. Li et al [10] stated that the successful operation of CMS is influenced by both structural issues like cell formation (CF) and operational issues that deal with scheduling. Wemmerlov and Hyer [11] mentioned that even though the researchers widely focus on $\mathrm{CF}$ problem, the cell design would be incomplete if not related to the operational issues like scheduling of the system. Taking into account the above points, a few research works have included scheduling, however in different manner in the CF problems and are: Arkat et al [12] addressed the CF problem with the objectives of minimum transportation cost and minimum makespan; Mak et al [13] considered objectives of minimizing total material travel distance and minimizing the sum of tardiness of all the products in a virtual cellular manufacturing system; Kesen et al [14] proposed scheduling methodology and machine assignment with alternate machine routing for a virtual manufacturing environment with a temporary part grouping and considered a weightbased approach for the objectives of minimizing makespan and total travel distance; Jeon and Leep [15], Egilmez and Süer [16] discussed a two-phase procedure for part-family formation in phase I and scheduling aspects and machine cell formation in phase II. However, Arkat et al [12] and Mak et al [13] have not considered machine duplications, which, if included, can minimize inter-cell moves and minimize makespan under alternate machine routing flexibilities. The weight-based multi-objective approach of Kesen et al [14] is often related to the subjective preferences of the designer to the two criteria, makespan and inter-cell move. The two-phase procedure proposed by Jeon and Leep [15] and Egilmez and Süer [16] is a sequential approach and lacks a concurrent approach of CMS issues. This paper is an attempt to develop a model to consider scheduling and CF decisions concurrently to overwhelm the above issues.

Besides, it is accepted that alternate routings, if available for any operation, has the capability of increasing the utilization of production resources of machine, labor, and tool. If an operation has an option of selecting a machine from a set of different alternatives, and the operation time is a function of the machine selected, then it is a scheduling problem with alternate part routing/process plan. The alternate part routing/process plan enhances effective capacity usage by smoother part flow and better balancing of machine loads in a flexible manufacturing system [17]. Chung et al [18] considered different processing sequences for the same part type. Jeon et al [19], Caux et al [3] and Tavakkoli-Moghaddam et al [7] have included alternate process routing by considering different machine types to do the same operation of a part type. Solimanpur and
Foroughi [20] have incorporated both alternate sequences in their alternate routings. However, all the alternate routing considerations ignore the concept of cross-flow operations under the decisions of duplicating machines in CMS problems. The cross-flow is the inter-cell movement of parts from parent cell to identical machines in another cell in spite of the availability of machines in the same cell. It is different from inter-cell exceptional element move where it is the movement of parts due to non-availability of machines in the parent cell. The admittance of the concept of cross-flow inter-cell move in the CF problems would lead to alternate machine routing and provides scheduling flexibility. Hence, the cross-flow concept paves way for cost minimization as a result of the possible reduction in schedule length and increase in machine utilization. Figure 1 illustrates the concept of cross-flow and exceptional element inter-cell moves. Consider a two cell CMS in which cell 1 has machines 1, 2, 3 and 5 and cell 2 has 2, 4, 5 and 6. Suppose that a part that belongs to cell 1 and its operations are to be carried out in the machines 1, 2, 3, 4 and 5, and in the sequence: 1-3-5-2-4, the operation on machine 4 can be done using the machine available in the cell 2 and the operation on machine 5 can be accomplished by using the machine 5 in cell 1 or cell 2 . The part undergoes cross-flow inter-cell movement when it is assigned to machine 5 in cell 2 in spite of the availability of machine 5 in cell 1 and exceptional element inter-cell flow to machine 4 in cell 2 due to non-availability of that machine in cell 1 .

The operational efficiency of a CF problem is generally influenced by the resource utilization and material flow of a CMS. Hence, the operational cost of CMS design is evaluated based on machine utility cost (MUC) and material handling cost (MHC). The MUC is based on cost per unit time of utilizing or hiring each machine-type and the time (i.e., makespan time) for which the system has to be utilized/hired for production of a certain demand. It is the machine-wise cost of using the system spread out equally over the expected life of the system. The MUC accounts machine, labor, power and overhead charges, and takes care of investment and labor cost of machines duplicated primarily to serve the purpose of minimizing inter-cell moves. In CMS models by [19, 21, 22], machine operating cost based on the processing time of parts is used as evaluation criteria. But MUC is different from machine operating cost in the way that MUC is based on schedule length and considers the time the parts are in the system. When there is a huge difference in the requirements and processing characteristics of the part-types, then makespan time varies considerably with different cell configurations. On these viewpoints that the inclusion of cross flow, scheduling and machine utility in $\mathrm{CF}$ decisions can pave way for the increase in the operational efficiency of CMS in addition to the other advantages of CMS. Taking these aspects into consideration, this paper presents a $\mathrm{CF}$ model integrated with scheduling and incorporates machine duplications 


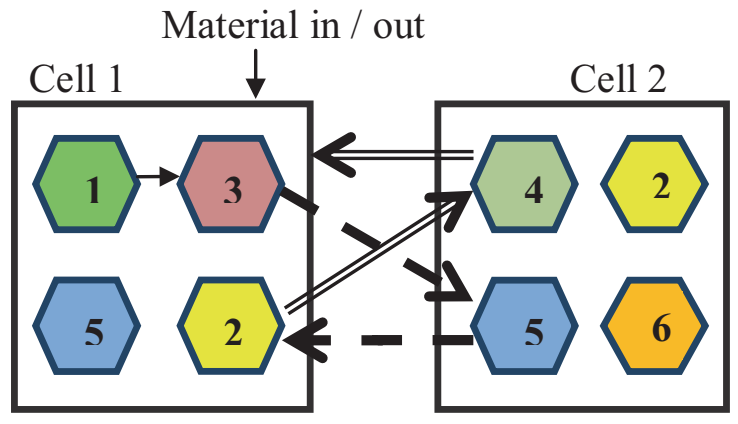

Part machining with cross-flow

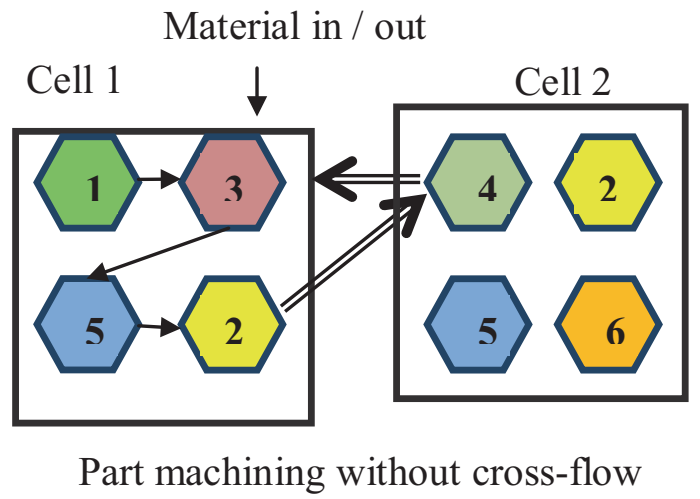

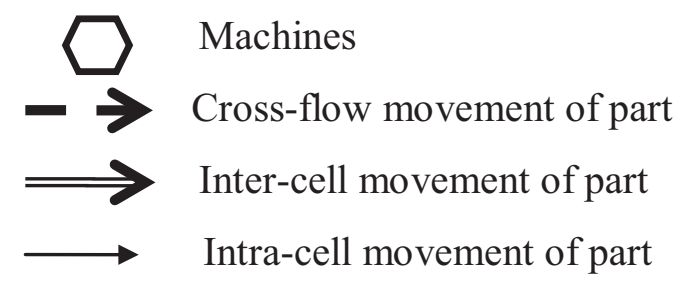

Figure 1. Cross-flow and exceptional element inter-cell flow of parts in CMS.

with cross flow concept to facilitate the design of CMS including operational issues in addition to the design issues.

The proposed CMS model deals with concurrently CF and scheduling decisions. Both the categories are NP-hard and the computation time to find any reasonable solution increases particularly with the size of the problem as the search space increases exponentially [23-25]. The mathematical formulations for CMS design are hard to implement for large-sized combinatorial problems due to computational complexities caused by larger, complex and poorly understood search space inherent to large-sized CMS problems [7, 26-28]. These complexities lead to the search for alternate ways to solve the real industrial problems and lead to the development of many heuristic algorithm based solution to cell formation problem. Although heuristic approaches do not guarantee to provide optimal solutions, they are useful in producing an acceptable solution in a reasonable time [7]. The popular $\mathrm{CF}$ algorithms like rank order clustering [29], MODROC [30], ZODIAC [31], CASE [32], Accord [33], etc. are based on heuristic approaches. As a result of CF problems complexity and with the increase in computer processing speed, recent research papers mostly use meta-heuristic like simulated annealing algorithm (SAA) [34], tabu search [35], bacteria foraging algorithm [36], particle swarm optimization (PSO) [37], hybrid genetic ant lion optimization algorithm (HGALO) [38]. A comprehensive review of genetic algorithm (GA) and artificial neural network (ANN) approaches for $\mathrm{CF}$ is given by Chattopadhyay et al [9]. On this concern, to improve the solution within a reasonable computational time, so that there would be a better chance of implementation among practitioners, a hybrid heuristic $(\mathrm{HH})$ that has "SAA embedded with GA" is developed to the CF integrated with scheduling decisions. The proposed heuristic solution methodology finds exceptional elements and thus identifies exceptional machines to be duplicated to reduce/avoid exceptional element inter-cell movement for a given $\mathrm{CF}$ solution and generates all $\mathrm{CF}$ configurations with or without exceptional machine duplications. Then the heuristic analyses each CF configuration using SAA for optimizing part operation assignment decisions considering cross-flow and GA for optimizing schedule decisions. The best configuration with the minimum cost of operation of all configurations is given as the optimal cell formation.

The rest of the paper is organized as follows. Section 2 describes the model with the environment, problem statement, objective function and mathematical formulation of the proposed CMS model. In section 3, proposed HH using SAA-GA solution methodology is elaborated with an illustrative example. Section 4 discusses the performance of the heuristic with computational experiences carried out on literature problems. Section 5 deals with conclusions and future research directions.

\section{Problem description}

The problem under study is a CMS design problem that includes cell formation and cell scheduling under crossflow. This section describes the CMS problem addressing environment, objective criterion, problem statement and mathematical formulation. 


\subsection{Environment}

There are $m$ machine-types (indexed as $j$ ) in a cellular manufacturing system under considerations and are to be grouped in $C$ number of cells (indexed as $c$ ). It needs to process $n$ parts (indexed as $i$ ) with each part $i$ has a specific processing sequence consisting of $K_{i}$ number of operations (indexed as $k$ ) and demand $d_{i}$ during the planning period. The machine required $j_{i k}$ and the unit processing time $t_{i k}$ for operation $O_{i k}\left(k^{\text {th }}\right.$ operation of part $\left.i\right)$ are given. All the parts are available at time zero and processing follows non-preemptive scheduling. The part subcontracting is not considered. The production scenario under consideration is a discrete part manufacturing that has to feed assembly and the production of items can be carried out as a single lot or more number of lots. Single lot production leads to more inventory. On the other hand, the set-up time cost increases linearly with lot sizes. Besides, synchronization of production with assembly is more complicated in the case of more number of lot sizes. Hence production centers that feed assembly operate as a single lot with buffers feeding assembly continuously. It is also to be noted that articles $[10,28,39]$ which have considered scheduling aspects of CMS have used the single lot. On these considerations, this paper considers a single lot. In CMS, there are usually 4-8 machines in a cell arranged in U-loop and thus intra-cell move time is less compared to inter-cell moves [10]. Most of the job shop scheduling problems include handling time in their processing times. On this background, this paper considers intra-cell movement time as small and included in the processing time. The model environment permits both inter-cell movements both of exceptional element and cross-flow types. The machine duplications in other cells have a cost advantage of reducing or eliminating exceptional element inter-cell moves and also, under cross-flow considerations, reduce schedule length by using the surplus capacity of the duplicated machines. On the other hand, the machine duplication when done in the same cell, though reduce makespan, it adds an additional machine cost and results only in marginal cost advantage. Thus, duplication in other cells is comparatively more advantageous as it reduces the cost of exceptional element inter-cell moves and schedule length simultaneously. Hence, this paper allows machine duplications within the system and not within each cell (i.e., a cell $\mathrm{c}$ can have only one machine of machine-type j).

\subsection{Problem statement}

The problem is to determine the optimal $\mathrm{CF}$ and the schedule for minimum total cost of operation of CMS, which comprises of machine utility cost (i.e., cost based on makespan), and inter-cell movement cost (i.e., includes both cross-flow inter-cell moves and exceptional element inter-cell moves) given the following data:
- Number of parts $n$, number of machine-types $m$, number of cells $C$,

- Parts related data: part processing characteristics for $K_{i}$ number of operations, machines required $j_{i k}$, unit processing time $t_{i k}$ for operation $O_{i k}$ and demand $d_{i}$,

- Cost related data: machine utility rate of machine-type $j\left(M U_{j}\right)$ per unit time, inter-cell movement cost $I C_{C^{\prime} c}$

\subsection{Objective criterion}

The objective of the model is to minimize the total cost of operation (TC) which is the sum of machine utility and inter-cell costs.

The machine utility cost (MUC) is evaluated by optimal makespan $\left(C_{\max }\right)$ which is the maximum completion time $C_{i K_{i}}$ of last operation (i.e., $K_{i}$ ) of part $i$ considering all the $n$ parts and the total machine utility rate. The machine utility rate of machine $j$ is fixed as $M U_{j}$ irrespective of the state whether the machine is working or idle. But, $M U_{j}$ differs with the machine running state and machine idle state. However, in the practical situation, machine and labor hiring charges should be considered for the entire period and only power consumption cost can be saved in the machine idle time. Hence, this work considers the same machine utility rate for machine working and idle states, as the savings on power consumption is usually comparatively lesser than other costs. The optimal schedule is determined considering the following job shop scheduling constraints like starting time $S_{i k}$ of operation $O_{i k}$ is always positive (i.e., $\geq 0$ ), the jobs are non-preemptive and part operations follow precedence relationship. It is assumed that the machine utility rate of each machine $j$ per unit time $\left(M U_{j}\right)$ is known. Equation (1) gives the MUC for a planning period.

$$
\mathrm{MUC}=\left(\sum_{c=1}^{C} \sum_{j=1}^{m} C_{\max } \times X_{j . c} \times M U_{j}\right)
$$

Where,

$X_{j . c}$ Binary integer variable that indicates the assignment of machine $j$ to cell $c$

$$
X_{j . c}= \begin{cases}1 & \text { if machine } j \text { is assigned to cell } c \\ 0 & \text { otherwise }\end{cases}
$$

The parts travel between two cells (i.e., inter-cell moves) at the time of cross-flow and exceptional element moves. The cost of transporting a part between any two cells depends on their locations in CMS, part weight and quantity. On the assumption that the difference in weights among the parts is negligible, the unit cost of transportation either for cross-flow or for exceptional element inter-cell moves between cell $\mathrm{c}^{\prime}$ and cell $c$ are dependent on the location of cells and quantity and is designated as $I C_{c^{\prime} c}$. 
Equation (2) gives the inter-cell movement cost (ICC) considering both cross-flow and exceptional moves.

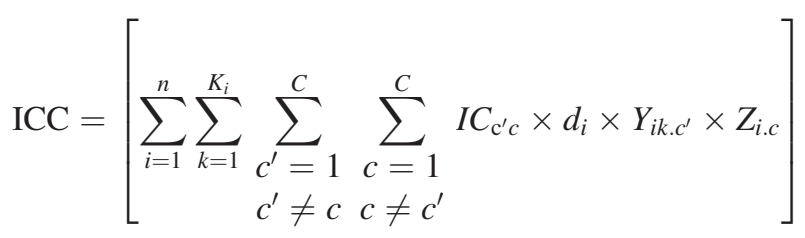

Where,

$X_{j_{i k} . c}$ Binary integer variable that indicates the assignment of machine $j_{i k}$ to cell $c$

$$
X_{j_{k} . c}= \begin{cases}1 & \text { if machine } j_{i k} \text { is assigned to cell } c \\ 0 & \text { otherwise }\end{cases}
$$

$Y_{i k . c}$ Binary integer variable that indicates operation $O_{i k}$ is assigned to cell $c$

$$
Y_{i k . c}= \begin{cases}1 & \text { if operation } O_{i k} \text { is assigned to cell } c \\ 0 & \text { otherwise }\end{cases}
$$

$Z_{i . c}$ Binary integer variable that indicates the assignment of part $i$ to cell $c$

$$
Z_{i . c}= \begin{cases}1 & \text { if part } i \text { is assigned to cell } c \\ 0 & \text { otherwise }\end{cases}
$$

Suppose, consider a CMS has to be designed for the manufacturing environment that cannot allow either cross-flow inter-cell movements or exceptional element inter-cell movements. Equation (2) when applied to such cases, cannot differentiate the type of inter-cell movement that is whether cross-flow or exceptional element movements. Thus, in order to address the manufacturing environments that cannot facilitate cross-flow or exceptional element inter-cell moves, the inter-cell cost (Equation (2)) is rewritten as Equation (3) which is the sum of two separate terms, one for cross-flow inter-cell move cost (CFC) and another for exceptional element intercell move cost (IEC) and are given by Equations (4) and (5), respectively. It is to be noted here that Equations (4) and (5) use different cost terms for cost of moving unit part from cell " $\mathrm{c}$ " to cell ' $c$ ' that is $\mathrm{CF}_{\mathrm{c}^{\prime} \mathrm{c}}$ and $\mathrm{EF}_{\mathrm{c}^{\prime} \mathrm{c}}$ for cross-flow and exceptional element inter-cell moves, respectively.

$$
\mathrm{ICC}=\mathrm{CFC}+\mathrm{IEC}
$$

Where,

$$
\begin{aligned}
& \mathrm{CFC}= \\
& {\left[\sum_{i=1}^{n} \sum_{k=1}^{K_{i}} \sum_{c^{\prime}=1}^{C} \sum_{c=1}^{C} C F_{\mathrm{c}^{\prime} c} \times d_{i} \times\left[X_{j_{i k} \cdot c} \times Y_{i k . c^{\prime}} \times Z_{i . c}\right]\right]}
\end{aligned}
$$

$$
\begin{aligned}
& \text { IEC }=
\end{aligned}
$$

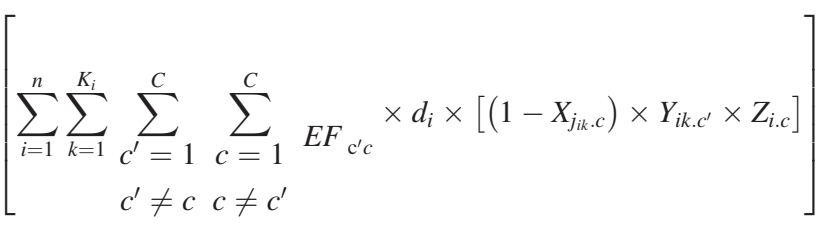

Hence, total cost of operation (TC) of CMS is formulated as the sum of all the above cost elements (i.e., MUC, CFC, IEC) as given in equation (6).

$$
\begin{aligned}
& \mathrm{TC}=\left(\sum_{c=1}^{C} \sum_{j=1}^{m} C_{\max } \times X_{j . c} \times M U_{j}\right)
\end{aligned}
$$

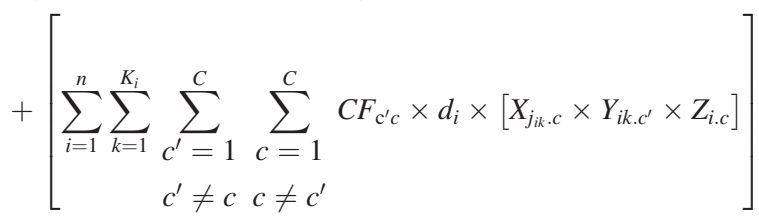

$$
\begin{aligned}
& +\left[\sum_{i=1}^{n} \sum_{k=1}^{K_{i}} \sum_{\substack{c^{\prime}=1 \\
c^{\prime} \neq c}}^{c} \sum_{\substack{c=1 \\
c \neq c^{\prime}}}^{c} E F_{\mathrm{c}^{\prime} c}\right. \\
& \times d_{i} \times\left[\left(1-X_{j k . c .}\right) \times Y_{i k . c^{\prime}} \times Z_{i . c}\right]
\end{aligned}
$$

The differentiation of cost terms as $\mathrm{CF}_{\mathrm{c}^{\prime} \mathrm{c}}$ and $\mathrm{EF}_{\mathrm{c}^{\prime} \mathrm{c}}$ has enabled to address different manufacturing environments by the way of assuming different values as given below:

- For manufacturing environment with no cross-flow facility: $C F_{c^{\prime} c}$ has assumed a very big value and $E F_{c^{\prime} c}=I C_{\mathrm{c}^{\prime} c}$ in Equation (6).

- For addressing no inter-cell facility environment: $C F_{c^{\prime} c}=I C_{\mathrm{c}^{\prime} c}$ and $E F_{c^{\prime} c}$ is assumed a very big value in Equation (6).

The optimization of Equation (6) for minimum total cost will subsequently eliminate cross-flow decisions or exceptional element move decisions based on their cost terms value. Table 1 shows the values of $\mathrm{CF}_{\mathrm{c}^{\prime} \mathrm{c}}$ and $\mathrm{EF}_{\mathrm{c}^{\prime} \mathrm{c}}$ so that the model can be adopted for different manufacturing environments with respect to inter-cell moves.

\subsection{Mathematical formulation}

The mathematical formulation of the CMS problem is as follows: 


$$
\begin{aligned}
& \text { Minimize } \mathrm{TC}=\left(\sum_{c=1}^{C} \sum_{j=1}^{m} C_{\max } \times X_{j . c} \times M U_{j}\right) \\
& +\left[\sum_{i=1}^{n} \sum_{k=1}^{K_{i}} \sum_{\substack{c^{\prime}=1 \\
c^{\prime} \neq c}}^{C} \sum_{\substack{c=1 \\
c \neq c^{\prime}}}^{C} C F_{\mathrm{c}^{\prime} c} \times d_{i}\right. \\
& \times\left[X_{j i k \cdot c} \times Y_{i k . c^{\prime}} \times Z_{i . c}\right] \\
& +\left[\sum_{i=1}^{n} \sum_{k=1}^{K_{i}} \sum_{\begin{array}{c}
c^{\prime}=1 \\
c^{\prime} \neq c
\end{array}}^{C} \sum_{\substack{c=1 \\
c \neq c^{\prime}}}^{C} E F_{\mathrm{c}^{\prime} c} \times d_{i} \times\left[\left(1-X_{j_{i k} . c}\right) \times Y_{i k . c^{\prime}} \times Z_{i . c}\right]\right]
\end{aligned}
$$

Subject to:

$$
\begin{gathered}
\sum_{c=1}^{C} Z_{i . c}=1 \quad \forall i \\
\sum_{i=1}^{n} Z_{i . c} \geq 1 \quad \forall c \\
\sum_{c=1}^{C} X_{j . c} \geq 1 \quad \forall j \\
\sum_{c=1}^{C} Y_{i k . c}=1 \quad \forall i, k \\
Y_{i k . c} \leq X_{j i k . c} \quad \forall i, k, c \\
S_{i k} \geq 0 \quad \forall i, k \\
C_{i k}-S_{i k}-\left(d_{i} \times t_{i k}\right)=0 \quad \forall i, k \\
S_{i(k+1)}-C_{i k} \geq 0 \quad \forall i, k=1 \ldots\left(K_{i}-1\right)
\end{gathered}
$$

$$
\begin{gathered}
\left(\left(Y_{i k . c} \times C_{i k}\right)-\left(Y_{p q . c} \times C_{p q}\right)\right) A_{i k p q . c} \\
-\left(\left(Y_{i k . c} \times C_{i k}\right)-\left(Y_{p q . c} \times C_{p q}\right)\right)\left(1-A_{i k p q . c}\right) \\
\geq A_{i k p q . c}\left(d_{p} \times t_{p q}\right)+\left(1-A_{i k p q . c}\right)\left(d_{p} \times t_{p q}\right) \\
\forall c,(i, k),(p, q), i \neq p, j_{p q}=j_{i k} \\
\left(\left(Y_{i k . c} \times C_{i k}\right)-\left(Y_{p q . c} \times C_{p q}\right)\right) A_{i k p q . c} \geq 0 \forall c,(i, k),(p, q), i / \\
=p, j_{p q}=j_{i k .} \\
C_{\max } \geq C_{i K_{i}} \quad \forall i \\
X_{j . c}, Y_{i k . c}, Z_{i . c} \in\{0,1\} \quad \forall i, k, j, c \\
A_{i k p q . c} \in\{0,1\} \quad \forall(i, k),(p, q), c
\end{gathered}
$$

where, $A_{i k p q . c}$ Binary integer variable that indicates the precedence relationship of operations $\mathrm{O}_{\mathrm{ik}}$ and $\mathrm{O}_{\mathrm{pq}}$ that are assigned to cell 'c'

\begin{tabular}{|c|c|c|c|c|}
\hline \multicolumn{2}{|l|}{ Environments } & \multicolumn{2}{|c|}{ Cost parameter values assigned } & \multirow[b]{2}{*}{ Remarks } \\
\hline $\begin{array}{l}\text { Exceptional } \\
\text { element } \\
\text { movement }\end{array}$ & $\begin{array}{l}\text { Cross-flow } \\
\text { movement }\end{array}$ & $\begin{array}{l}\text { Exceptional element } \\
\text { cost/part }\left(E F_{c^{\prime} c}\right)\end{array}$ & $\begin{array}{c}\text { Cross-flow } \\
\text { movement cost/part } \\
\qquad\left(C F_{c^{\prime} c}\right)\end{array}$ & \\
\hline Allowed & Allowed & $\begin{array}{l}\text { Inter-cell movement } \\
\text { cost/part }\left(I C_{c^{\prime} c}\right)\end{array}$ & $\begin{array}{l}\text { Inter-cell movement } \\
\text { cost/part }\left(I C_{c^{\prime} c}\right)\end{array}$ & $\begin{array}{l}\text { Applicable for the environment that allows both inter- } \\
\text { cell moves }\end{array}$ \\
\hline Not allowed & Allowed & Very big number & $\begin{array}{l}\text { Inter-cell movement } \\
\text { cost/part }\left(I C_{c^{\prime} c}\right)\end{array}$ & $\begin{array}{l}\text { Applicable for the environment with cross-flow and } \\
\text { without exceptional element inter-cell moves }\end{array}$ \\
\hline Allowed & $\begin{array}{l}\text { Not } \\
\text { allowed }\end{array}$ & $\begin{array}{l}\text { Inter-cell movement } \\
\text { cost/part }\left(I C_{c^{\prime} c}\right)\end{array}$ & Very big number & $\begin{array}{l}\text { Applicable for the environment with the exceptional } \\
\text { element and without cross-flow inter-cell moves }\end{array}$ \\
\hline
\end{tabular}

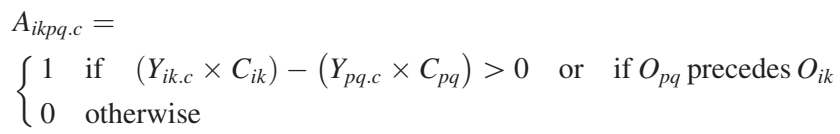

Equation (7) gives the objective function and its first term is machine utility cost (MUC) and whereas second and third are cross-flow inter-cell move cost (CFC) and exceptional element inter-cell move cost (IEC), respectively. Constraint 8 assures each and every part $i$ is assigned to only one cell $c$ of $C$ cells. Constraints 9 and 10 ensure that each cell $c$ should have at least one part $i$ and one machine $j$, respectively. Constraint 11 checks that each operation $O_{i k}$ is assigned to only one cell. Constraint 12 satisfies the condition that an operation $O_{i k}$ is assigned to the cell, only when the machine $j_{i k}$ required for that operation is available in that cell and further it checks availability of cross-flow for each part operation. Constraint 13 ensures that start time $\left(S_{i k}\right)$ of an operation $\left(O_{i k}\right)$ is always positive. The condition that the parts are non-preemptive is assured in the constraint 14. In this constraint, the difference between the completion time $C_{i k}$ and the starting time $S_{i k}$ of an operation $O_{i k}$ is equal to its processing time

Table 1. Values of $\mathrm{CF}_{\mathrm{c}^{\prime} \mathrm{c}}$ and $\mathrm{EF}_{\mathrm{c}^{\prime} \mathrm{c}}$ for different $\mathrm{CMS}$ model environments. 
$d_{i} \times t_{i k}$. Constraint 15 ensures that the completion time of an operation $O_{i k}$ should be equal or less than the start time its next operation i.e., $O_{i k+1}$ and hence it checks the precedence relationship. Constraints 16 and 17 control the condition that no two operations are processed simultaneously on the same machine. In constraint 16, the difference between the completion times of two operations $O_{i k}$ and $O_{p q}\left(O_{p q}\right.$ precedes $\left.O_{i k}\right)$ that requires the same machine $j$ available in cell $c$ should be greater than or equal to the total operation time of the later operation. Constraint 17 assures the precedence relationship among operations done on the machine $j$ available in cell $c$. Constraint 18 evaluates the makespan time (i.e., $C_{\max }$ ) which is the maximum completion time of the last operation (i.e., $C_{i K i}$ ) of all the jobs. Constraints 19 and 20 represent binary integer requirements of decision variables and control variable.

\section{Solution methodology: Hybrid heuristic SAA embedded with GA}

The CF decisions of the part and machine assignment to cells and part operations assignment with alternative routes as a result of cross-flow are 0-1 integer programming and scheduling parameters are discrete in nature. Hence, this model belongs to the combinatorial optimization problem categorized under the class of NP-hard problems. The combinatorial explosion occurs with the increase in the number of machines to be duplicated and thus corresponding increase in the number of possible cross-flows for the part operations. The complexity further increases with the combinatorial nature of scheduling constraints and $\mathrm{CF}$ constraints. The $\mathrm{CF}$ problems with machine duplications $[5,6]$ and cell scheduling problems $[28,40]$ are dealt mostly as separate problems by researchers as these problems when done as a separate entity itself is complex to formulate and solve. Hence, we have proposed a search space reduction by approaching the problem with initial part-machine grouping and evolve machine duplication and operation assignment decisions with cross-flow consideration and find a feasible schedule with the minimum cost of operation. Due to this complex nature, a heuristic approach is proposed to find a near optimal solution in a reasonable computational time. The meta-heuristics are widely used as they rely on randomization to avoid being trapped in local optimum and they are often intelligent search heuristics based on nature and on neighborhood search procedures [41]. The literature addresses the variety of meta-heuristics: Simulated Annealing Algorithm 'SAA' [34]; Tabu Search 'TS' [35]; Genetic Algorithm 'GA' [42] and Artificial Neural Network 'ANN' [9]. Zolfaghari and Liang [43] used SAA, GA, and TS for CF problem and concluded that SAA outperforms GA and TS as later two approaches solution quality greatly depend on search parameters and conditions specified whereas in SAA the selection of search parameter is simple. Further, SAA avoids being trapped in local optima by accepting the worst solutions in the initial stages of the search process [40]. However, the efficiency of metaheuristics, in general, lies with the design of solution improvement methods and search capabilities (i.e., crossover, mutation, perturbation, quenching rate, number of iterations and so on) and no clear distinction is available for adopting a particular methodology. Most often, the methodology has been selected based on the nature and number of solutions of the search space. And also, the algorithms are combined to bring forth added advantages due to hybridization $[44,45]$. On these considerations of the simplicity of SAA and the exhaustive search capability of $\mathrm{GA}$, this paper proposes hybrid heuristic $(\mathrm{HH})$ based on SAA-GA for finding an optimal/near optimal solution. The logic of the proposed heuristic is as follows: First, part machine groups are formed based on minimum exceptional elements (EE) to have minimum EE inter-cell moves. Secondly, the possible machine duplications in the cells are generated to avoid or reduce EE inter-cell moves and to facilitate cross flow leading to reduced make-span. The third part evaluates the different configurations for minimum total cost of operation (TC) based on the decisions on operation assignments (schedule) considering cross-flow using SAA-GA. Finally, the best configuration with respect to minimum TC is sorted from evaluated configurations. Figure 2 outlines the structure of the proposed $\mathrm{HH}$ using SAA - GA. This section delineates the proposed $\mathrm{HH}$ with an illustration.

\subsection{Input module}

In this module, the data pertaining to the problem as stated in the problem description are given as input. Table 2 provides part processing data of 6 parts -6 machines - 2 cells $\mathrm{CF}$ problem, which are generated using uniform distribution in the range of 3-12 for processing time $\left(t_{i k}\right), 1-6$ for machine number of operations and 100-250 for demand $\left(d_{i}\right)$. The machine-wise utility rate of machine ' $\mathrm{j}$ ' per unit time $\mathrm{MU}_{\mathrm{j}}$ is determined by spreading the total machine cost over the expected lifetime of the machine ' $\mathrm{j}$ '. Table 3 illustrates the estimation of $\mathrm{MU}_{\mathrm{j}}$ per minute for each machine $\mathrm{j}$ assuming expected life period as 5 years with 300 working days per year and 16 working hours per day. Table 4 provides per unit cost for exceptional element and cross flow inter-cell moves to the example problem on the assumption that cell layout is linear.

\subsection{Part-machine grouping module}

The part assignment decisions $\left(\mathrm{Z}_{\mathrm{i} . \mathrm{c}}\right)$ and thus initial machine grouping $\left(X_{j . c}\right)$ without machine duplications are made based on part processing requirements. The proposed heuristic is structured to adapt the part-machine grouping 


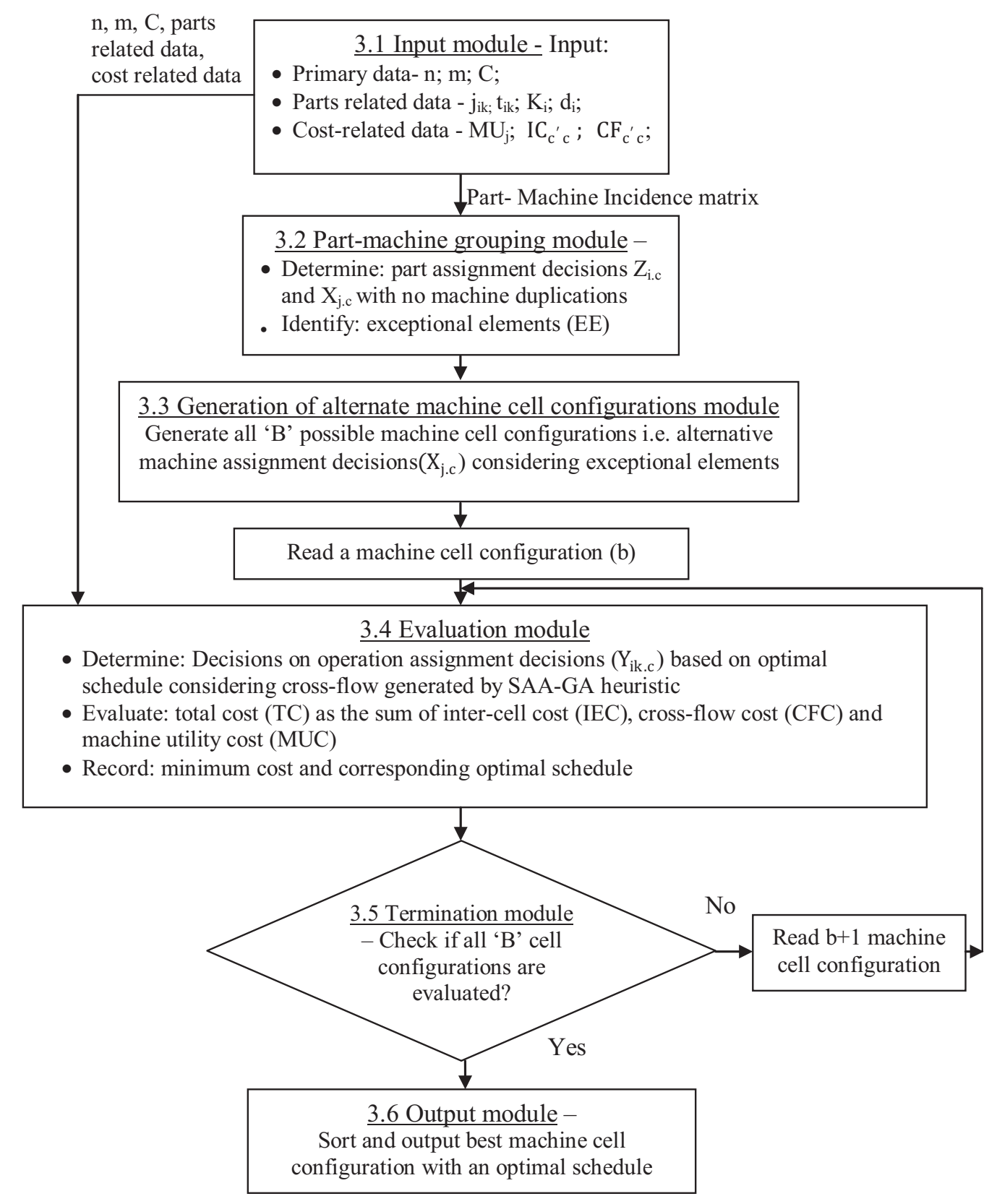

Figure 2. Structure of the proposed HH procedure.

by any one of the effective cell formation methods. Hence, the solution quality is dependent on the quality of adapted cell formation method. For the illustrative problem, rank order clustering (ROC) is used to provide part-machine grouping as ROC is simple and suits smaller size problems. Table 5 shows part-family and machine cell grouping obtained using ROC. The parts 1, 4, 5, machines 1, 3, 5 are assigned to cell 1 and parts 2, 3, 6, machines 2, 4, 6 are assigned to cell 2 (i.e., set of parts in cell $1\left(Z_{i .1}\right)=\{1,4,5\}$, set of parts in cell $2\left(\mathrm{Z}_{\mathrm{i} .2}\right)=\{2,3,6\}$, set of machines in cell $1 \quad\left(X_{j .1}\right)=\{1,3,5\}$, set of machines in cell 2
$\left.\left(X_{j .2}\right)=\{2,4,6\}\right)$. It is noted from table 5 that there are 3 exceptional elements (EE) and thus 3 EE inter-cell moves (shown as italic ' 1 ') required for the considered cell grouping.

\subsection{Generation of alternative machine cell configurations module}

This module elaborates a combinatorial design for the generation of various alternative machine cell configuration and thus alternative decisions on machine assignment 
Table 2. Processing characteristics of example problem.

\begin{tabular}{|c|c|c|c|c|c|}
\hline \multirow[b]{2}{*}{ Part no. (i) } & \multirow[b]{2}{*}{ Operation details } & \multicolumn{3}{|c|}{$\begin{array}{l}\text { Operation no. } \\
\text { (k) }\end{array}$} & \multirow[b]{2}{*}{ Demand $\left(\mathrm{d}_{\mathrm{i}}\right)$} \\
\hline & & 1 & 2 & 3 & \\
\hline \multirow[t]{2}{*}{1} & Machine no. $\left(\mathrm{j}_{1 \mathrm{k}}\right)$ & 3 & 1 & 5 & 150 \\
\hline & Processing time $\left(\mathrm{t}_{1 \mathrm{k}}\right)$ & 10 & 10 & 8 & \\
\hline \multirow[t]{2}{*}{2} & Machine no. $\left(\mathrm{j}_{2 \mathrm{k}}\right)$ & 5 & 2 & 6 & 200 \\
\hline & Processing time $\left(\mathrm{t}_{2 \mathrm{k}}\right)$ & 8 & 10 & 5 & \\
\hline \multirow[t]{2}{*}{3} & Machine no. $\left(\mathrm{j}_{3 \mathrm{k}}\right)$ & 6 & 4 & & 250 \\
\hline & Processing time $\left(\mathrm{t}_{3 \mathrm{k}}\right)$ & 10 & 3 & & \\
\hline \multirow[t]{2}{*}{4} & Machine no. $\left(\mathrm{j}_{4 \mathrm{k}}\right)$ & 1 & 6 & 5 & 150 \\
\hline & Processing time $\left(\mathrm{t}_{4 \mathrm{k}}\right)$ & 5 & 12 & 9 & \\
\hline \multirow[t]{2}{*}{5} & Machine no. $\left(\mathrm{j}_{5 \mathrm{k}}\right)$ & 5 & 1 & 3 & 120 \\
\hline & Processing time $\left(\mathrm{t}_{5 \mathrm{k}}\right)$ & 6 & 5 & 9 & \\
\hline \multirow[t]{2}{*}{6} & Machine no. $\left(\mathrm{j}_{6 \mathrm{k}}\right)$ & 4 & 3 & 2 & 180 \\
\hline & Processing time $\left(\mathrm{t}_{6 \mathrm{k}}\right)$ & 10 & 10 & 6 & \\
\hline
\end{tabular}

parameter $\left(X_{j . c}\right)$. The presence of exceptional elements (EE) brings forth the possibilities of certain machines (i.e., exceptional machines) to be duplicated to avoid or reduce exceptional element inter-cell moves. These machine duplications enable generation of various alternative machine cell configuration that is to be evaluated for the optimum total cost of operation and duplications are based on following strategies.

- Full exceptional machine duplications where all the exceptional machines are duplicated in the required cell and hence there is no exceptional element intercell movement but can have cross-flow inter-cell movement.

- Partial exceptional machine duplications where exceptional machines are duplicated partially in the required cell and hence there are reduced exceptional element movements and can have cross-flow movement.

- No machine duplication where no machines are duplicated and there is exceptional element movement and no cross-flow movement.
In this approach, the alternative $\mathrm{CF}$ are evolved using the enumerative combinatorics which enables the counting of all possible structures of a given kind and size when certain criteria are met. In the combinatorial design of smaller cases, it is possible to count the number of combinations. For the developed model, considering exceptional machine duplications, if there are ' $x$ ' exceptional machines to be duplicated and considering ' $y$ ' combinations at a time without repetitions and number of combinations is denoted in elementary combinatorics texts by $\mathrm{C}(\mathrm{x}, \mathrm{y})$. In smaller enumerative combinatorics cases, the various possible combinations ' $\mathrm{b}$ ' are finite and total ' $\mathrm{B}$ ' combinations are countable using the counting function given by equation (21).

$$
B=\sum_{y=0}^{x} C(x, y)=\sum_{y=0}^{x} \frac{x !}{y !(x-y) !}
$$

For the example problem in table 5, there are $3 \mathrm{EE}$ with $1 \mathrm{EE}$ in cell1 and 2EE's in cell 2 and it needs 3 machines that are machine 6 in cell 1 and machine 5 and 3 in cell 2 to be duplicated to eliminate exceptional element inter-cell movements. The proposed model can have combinations of no machine duplication $(\mathrm{C}(3,0))$, all 3 machines $(\mathrm{C}(3,3))$ to be duplicated (i.e., full machine duplication) and 1 or 2 machines $(\mathrm{C}(3,1), \mathrm{C}(3,2))$ can be duplicated (i.e., partial machine duplication). Thus, altogether, the given problem, when evaluated by equation (19), can have 8 (i.e., $\mathrm{B}=8$ ) possible machine cell configurations and each ' $b$ ' combination with duplicated machine numbers shown as underlined and italic are given in table 6.

Table 4. Exceptional element and cross-flow inter-cell move cost for the unit part.

\begin{tabular}{lcr}
\hline & \multicolumn{2}{c}{ To } \\
\cline { 2 - 3 } From & Cell 1 & Cell 2 \\
\hline Cell 1 & 0 & 10 \\
Cell 2 & 10 & 0 \\
\hline
\end{tabular}

Table 3. Machine utility rate $\left(\mathrm{MU}_{\mathrm{j}}\right)$.

\begin{tabular}{|c|c|c|c|c|c|c|c|}
\hline \multirow{2}{*}{$\begin{array}{l}\text { Row } \\
\text { No. }\end{array}$} & \multirow[b]{2}{*}{ Particulars } & \multicolumn{6}{|c|}{ Machine $\mathrm{j}$} \\
\hline & & 1 & 2 & 3 & 4 & 5 & 6 \\
\hline 1 & $\begin{array}{l}\text { Machine cost for its expected life period (Purchase } \\
\text { cost }+ \text { Overhead }+ \text { Maintenance cost }- \text { salvage value) }\end{array}$ & 1000000 & 1500000 & 1000000 & 1000000 & 400000 & 700000 \\
\hline 2 & $\begin{array}{c}\text { Operating cost during its life period (labour }+ \text { power }+ \\
\text { overheads) }\end{array}$ & 1880000 & 660000 & 1160000 & 440000 & 320000 & 452000 \\
\hline 3 & $\begin{array}{c}\text { Expected life period in minutes (assuming } 5 \text { years } \times 300 \\
\text { days/year } \times 16 \text { hours/day } \times 60 \mathrm{~min} \text { ) }\end{array}$ & 1440000 & 1440000 & 1440000 & 1440000 & 1440000 & 1440000 \\
\hline 4 & Machine utility rate per minute $\operatorname{MU}_{\mathrm{j}}(\operatorname{Row}(1+2) / \operatorname{Row} 3)$ & 2 & 1.5 & 1.5 & 1 & 0.5 & 0.8 \\
\hline
\end{tabular}


Table 5. Cell formation by ROC method for example problem.

\begin{tabular}{|c|c|c|c|c|c|c|}
\hline \multirow[b]{3}{*}{$\begin{array}{c}\text { Part } \\
\text { no. } \\
\text { (i) }\end{array}$} & \multicolumn{6}{|c|}{ Machine no. (j) } \\
\hline & \multicolumn{3}{|c|}{ Cell 1} & \multicolumn{3}{|c|}{ Cell 2} \\
\hline & 5 & 1 & 3 & 6 & 2 & 4 \\
\hline 1 & 1 & 1 & 1 & & & \\
\hline 5 & 1 & 1 & 1 & & & \\
\hline 4 & 1 & 1 & & 1 & & \\
\hline 2 & 1 & & & 1 & 1 & \\
\hline 6 & & & 1 & & 1 & 1 \\
\hline 3 & & & & 1 & & 1 \\
\hline
\end{tabular}

Italic '1's indicate exceptional elements

\subsection{Evaluation module}

This module evaluates each $\mathrm{CF}$ configuration (i.e., known $\mathrm{Z}_{\mathrm{i} . \mathrm{c}}, \mathrm{X}_{\mathrm{j} . \mathrm{c}}$ ) in terms of total cost of operation (TC) by using the input of cost related data, part processing data. The assignment of operations to the cells $\left(Y_{i k . c}\right)$ and their completion time $\left(C_{i k}\right)$ influence TC. In order to determine them, a SAA integrated with GA is developed. The SAA evolves optimum alternate machine choices along with its optimal schedule generated by GA and evaluates the objective of minimum TC. Figure 3 shows the schematic structure of the HH search process.

Step 1 - Read Input data: The SAA-GA heuristic search process starts with reading parts and cost related data given in section 3.1 and cell related data of part assignments $\left(\mathrm{Z}_{\mathrm{i} . \mathrm{c}}\right)$ from table 5 and machine assignment $\left(X_{\text {j.c }}\right)$ from table 6 . The search process is illustrated by a machine cell configuration with full exceptional machine duplications (i.e., $\mathrm{b}=1$ in table 6 with part and machine assignments as $Z_{\text {i.1 }}=\{1,4,5\}, \quad Z_{i .2}=\{2,3,6\}, \quad X_{j .1}=\{1,3,5,6\}$, $\left.X_{\mathrm{j} .2}=\{2,3,4,5,6\}\right)$.

Step 2 - Identification of operations with alternate machine choices: With the known machine assignment decisions $\left(\mathrm{X}_{\mathrm{j} . \mathrm{c}}\right)$ and the part assignment decisions $\left(\mathrm{Z}_{\mathrm{i} . \mathrm{c}}\right)$ to the cells ' $\mathrm{c}$ ' and considering cross-flow, the operations that involve the duplicated machines are the one with alternate machine route choices. Table 7 lists all such operations that can have alternate machine assignments and provides alternate route choice numbers.

Step 3 - Initialisation of SAA parameters: The SAA approach requires an initial guess for parameter values and initialization of those values. The initial temperature $\left(\mathrm{T}_{0}\right)$ need to be large enough to enable the algorithm to move off a local minimum but small enough to move off a global minimum and also this value is defined based on applications objective value [46] and $\mathrm{T}_{0}$ is taken as 4500. The number of iterations for each temperature $\left(\mathrm{IT}_{\max }\right)$ is often related to the search space and in this algorithm and it varies with the number of operations with alternate machine route choices ('a') and hence the search space.
Table 6. Alternate machine cell configurations for example problem.

\begin{tabular}{|c|c|c|c|}
\hline $\begin{array}{l}\text { Strategy } \\
\text { no. 'b' }\end{array}$ & $\begin{array}{c}\text { Type of machine duplication } \\
\text { strategy }\end{array}$ & $X_{j .1}$ & $X_{j .2}$ \\
\hline 1 & $\begin{array}{c}\text { Full machine duplication-all } 3 \\
\text { machines duplicated }\end{array}$ & $1,3,5, \underline{6}$ & $2,4,6, \underline{3,5}$ \\
\hline 2 & $\begin{array}{c}\text { Partial machine duplication-2 } \\
\text { machines duplicated }\end{array}$ & $1,3,5, \underline{6}$ & $2,4,6, \underline{5}$ \\
\hline 3 & $\begin{array}{c}\text { Partial machine duplication-2 } \\
\text { machines duplicated }\end{array}$ & $1,3,5, \underline{6}$ & $2,4,6, \underline{3}$ \\
\hline 4 & $\begin{array}{c}\text { Partial machine duplication-2 } \\
\text { machines duplicated }\end{array}$ & $1,3,5$ & $2,4,6, \underline{3,5}$ \\
\hline 5 & $\begin{array}{l}\text { Partial machine duplication-1 } \\
\text { machine duplicated }\end{array}$ & $1,3,5, \underline{6}$ & $2,4,6$ \\
\hline 6 & $\begin{array}{l}\text { Partial machine duplication-1 } \\
\text { machine duplicated }\end{array}$ & $1,3,5$ & $2,4,6, \underline{5}$ \\
\hline 7 & $\begin{array}{c}\text { Partial machine duplication-1 } \\
\text { machine duplicated }\end{array}$ & $1,3,5$ & $2,4,6, \underline{3}$ \\
\hline 8 & No machine duplications & $1,3,5$ & $2,4,6$ \\
\hline
\end{tabular}

Underlined and italised machine number indicates duplicated machines

Thus, IT $_{\max }$ is taken as ' $\mathrm{a}$ '. The search process proceeds until the current temperature $\left(\mathrm{T}_{\mathrm{i}}\right)$ is above the final temperature $\left(T_{f}\right)$ whose value is 500 . Table 8 lists various SAA search parameters value used in this algorithm.

Step 4 - Generation of SAA String: The SAA approach requires an initial SAA string $\left(\mathrm{SA}_{\mathrm{i}}\right)$ to start the search process. In the proposed algorithm, the length of the SAA string is decided by the number of operations with alternate machine choices. If there are ' $a$ ' operations that have alternate machine choices, the length of the SAA string is taken as ' $a$ '. Then, the initial SAA String $\left(\mathrm{SA}_{\mathrm{i}}\right)$ is generated with the string values being alternate machine route choice number and is generated randomly. For instance, string $\mathrm{SA}_{\mathrm{i}}$ given below shows a SAA string of length 10 with the alternate route choice number from table 7 .

$$
S A_{i}=\{1,1,2,1,2,2,1,1,2,2\}
$$

The fourth value of string $\mathrm{SA}_{\mathrm{i}}$ is 1 and the value indicates that the operation $\mathrm{O}_{23}$ is assigned to the machine of route choice number 1 i.e., machine 6 in cell 1 and this particular operation assignment undergoes a cross-flow movement of parts.

Step 5- Fitness Evaluation for SAA by GA based scheduler: After generating a SAA string $\left(\mathrm{SA}_{\mathrm{i}}\right)$, the string values are decoded using alternate machine route choice number and therefore, operation assignment for operations with alternate machine choices are known (i.e., $\mathrm{Y}_{\text {ik.c }}$ are known $\forall \mathrm{i}, \mathrm{k})$. The cross-flow cost $\left(\mathrm{CFC}_{\mathrm{i}}\right)$ for the decoded string $\mathrm{SA}_{\mathrm{i}}$ can be derived using equation (2). Table 9 gives the decoded string values for the SAA string $\mathrm{SA}_{\mathrm{i}}$ shown in step 4.

It is noted from table 9 that operations $\mathrm{O}_{23}, \mathrm{O}_{42}, \mathrm{O}_{53}$ has cross-flow movements. As the machine cell configuration 


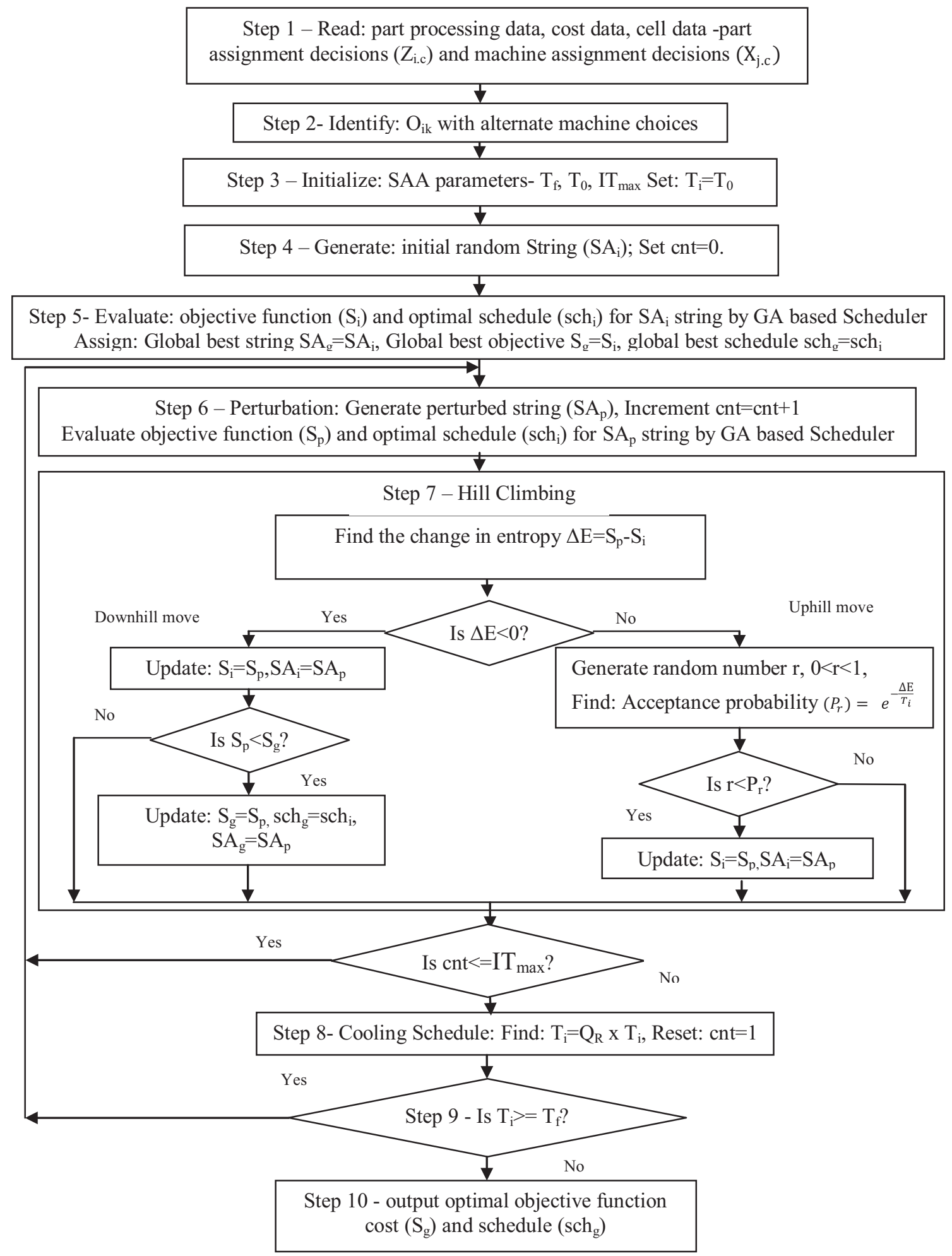

Figure 3. Structure of SAA-GA search process of HH.

(b) is known, the exceptional element inter-cell movement cost $\left(\mathrm{IEC}_{\mathrm{b}}\right)$ and total machine utility rate $\left(\mathrm{MUR}_{\mathrm{b}}\right)$ of configuration ' $b$ ' can be determined. Equation (22) gives the total machine utility rate (MUR).

$$
\operatorname{MUR}=\sum_{\mathrm{c}=1}^{\mathrm{C}} \sum_{\mathrm{j}=1}^{\mathrm{m}} \mathrm{X}_{\mathrm{j} . \mathrm{c}} \times \mathrm{MU}_{\mathrm{j}}
$$


Table 7. Alternate machine route choices for CF configuration considered.

\begin{tabular}{llllllllllll}
\hline Operation $\left(\mathrm{O}_{\mathrm{ik}}\right)$ & & $\mathrm{O}_{11}$ & $\mathrm{O}_{13}$ & $\mathrm{O}_{21}$ & $\mathrm{O}_{23}$ & $\mathrm{O}_{31}$ & $\mathrm{O}_{42}$ & $\mathrm{O}_{43}$ & $\mathrm{O}_{51}$ & $\mathrm{O}_{53}$ & $\mathrm{O}_{62}$ \\
\hline $\mathrm{j}_{\mathrm{ik}}(\mathrm{c})$ machine no (cell no) & Route 1 & $3(1)$ & $5(1)$ & $\underline{5(1)}$ & $\underline{6(1)}$ & $\underline{6(1)}$ & $6(1)$ & $5(1)$ & $5(1)$ & $3(1)$ & $\underline{3(1)}$ \\
& Route 2 & $\underline{3(2)}$ & $\underline{5(2)}$ & $\underline{5(2)}$ & $\underline{6(2)}$ & $\underline{6(2)}$ & $\underline{6(2)}$ & $\underline{5(2)}$ & $\underline{5(2)}$ & $\underline{3(2)}$ & $\underline{3(2)}$ \\
\hline
\end{tabular}

Underlined and italised jik(c) indicates cross-flow, Oik represents kth operation of part i

Table 8. SAA search parameters.

\begin{tabular}{lc}
\hline Parameters & Value \\
\hline Initial temperature $\left(\mathrm{T}_{0}\right)$ & 4500 \\
Final temperature $\left(\mathrm{T}_{\mathrm{f}}\right)$ & 500 \\
Maximum iterations per temperature $\left(\mathrm{IT}_{\max }\right)$ & $\mathrm{a}$ \\
\hline
\end{tabular}

For instance, for the considered machine cell configuration of full exceptional machine duplication, there is no exceptional element inter-cell movement and hence $\mathrm{IEC}_{\mathrm{b}-}$ $=0$. The machine assignment of $X_{j .1}=\{1,3,5,6\}$ and $X_{j .2}=\{2,3,4,5,6\}$ for configuration $b=1$ enables determination of $\mathrm{MUR}_{\mathrm{b}}$ and its value is 10.1. At this stage of evaluation, the machine utility cost $\left(\mathrm{MUC}_{\mathrm{i}}\right)$ of String $\mathrm{SA}_{\mathrm{i}}$ is the only unknown and it requires optimal make-span time $\left(\mathrm{M}_{\mathrm{i}}\right)$ derived from optimal or near optimal schedule $\left(\mathrm{sch}_{\mathrm{i}}\right)$ of a string $\mathrm{SA}_{\mathrm{i}}$. The make-span time of the system is the time to complete all the parts in all the cells. In the proposed heuristic approach, the optimal make-span time is found by GA based scheduler proposed by Jawahar et al [47]. The scheduler produces a feasible schedule satisfying the job-shop scheduling constraints and evaluates using makespan time as fitness parameter. The $\mathrm{M}_{\mathrm{i}}$ determined by GA based scheduler is utilized for evaluation $M_{U C}$ for string $\mathrm{SA}_{\mathrm{i}}$ using equation (1). Equation (23) gives the SAA objective function $\left(\mathrm{S}_{\mathrm{i}}\right)$. Table 10 illustrates the fitness evaluation for string $\mathrm{SA}_{\mathrm{i}}$.

$$
\begin{aligned}
\mathrm{S}_{\mathrm{i}} & =\mathrm{MUC}_{\mathrm{i}}+\mathrm{CFC}_{\mathrm{i}}+\mathrm{IEC}_{\mathrm{b}} \\
& =\left(\mathrm{M}_{\mathrm{i}} \times \mathrm{MUR}_{\mathrm{b}}\right)+\mathrm{CFC}_{\mathrm{i}}+\mathrm{IEC}_{\mathrm{b}}
\end{aligned}
$$

Step 6 - Perturbation: In this proposed approach, the perturbation is done to explore the neighborhood of the current solution. The perturbed SAA String $\left(\mathrm{SA}_{\mathrm{p}}\right)$ is generated by selecting two random integers in the range of 1'a' (a-number of operations with alternate machine choices) and randomly assigning cell identifier to the selected random positions. For instance, the perturbed string $\mathrm{SA}_{\mathrm{p}}$ formed from string $\mathrm{SA}_{\mathrm{i}}$ is given below. The shown strings choose randomly $4^{\text {th }}$ and $7^{\text {th }}$ positions and randomly assign cell identifier as 2 and 1, respectively.

$$
\begin{aligned}
\mathrm{SA}_{i} & =\{1,1,2,1,2,2,1,1,2,2\} \\
\mathrm{SA}_{\mathrm{p}} & =\{1,1,2,2,2,2,1,1,2,2\}
\end{aligned}
$$

The objective function $\left(S_{p}\right)$ of each perturbated string $\left(\mathrm{SA}_{\mathrm{p}}\right)$ is evaluated using fitness evaluation detailed in previous step. Table 11 illustrates the fitness evaluation of perturbated string $\mathrm{SA}_{\mathrm{p}}$.

Step 7 - Hill climbing: The global best solution $\left(\mathrm{S}_{\mathrm{g}}\right)$ and global best schedule $\left(\operatorname{sch}_{\mathrm{g}}\right)$ are initialized with the initial SAA string values and further solution improvements and their updation with $\mathrm{S}_{\mathrm{g}}$ and $\mathrm{sch}_{\mathrm{g}}$ are decided in this step. The acceptance probability $\left(\mathrm{P}_{\mathrm{r}}\right)$ of accepting a poor perturbed solution $\left(\mathrm{S}_{\mathrm{p}}\right)$ when it is poorer than the current solution $\left(\mathrm{S}_{\mathrm{i}}\right)$ and thus change in entropy $(\Delta \mathrm{E})$ greater than 0 and is given

\begin{tabular}{|c|c|c|}
\hline $\begin{array}{l}\text { Cost } \\
\text { parameter }\end{array}$ & Cost & Remarks \\
\hline $\begin{array}{l}\text { Machine } \\
\text { utility cost } \\
\left(\text { MUC }_{\mathrm{i}}\right)\end{array}$ & 51,510 & $\begin{array}{c}\mathrm{MUC}_{\mathrm{i}}=\mathrm{M}_{\mathrm{i}} \times \mathrm{MUR}_{\mathrm{b}} \\
(5100 \times 10.1)\end{array}$ \\
\hline $\begin{array}{l}\text { Cross-flow } \\
\text { inter-cell }\end{array}$ & 5700 & $\begin{array}{c}\mathrm{O}_{23}, \mathrm{O}_{42}, \\
\text { movements }\end{array}$ \\
\hline $\begin{array}{l}\text { movement } \\
\text { cost }\left(\mathrm{CFC}_{\mathrm{i}}\right)\end{array}$ & & $(200 \times 10+250 \times 10+120 \times 10)$ \\
\hline $\begin{array}{l}\text { Exceptional } \\
\text { element } \\
\text { inter-cell } \\
\text { movement } \\
\text { cost }\left(\text { IEC }_{\mathrm{b}}\right)\end{array}$ & 0 & $\begin{array}{c}\text { No exceptional element } \\
\text { movement }\end{array}$ \\
\hline $\begin{array}{l}\text { objective } \\
\text { function } \mathrm{S}_{\mathrm{i}} \\
\text { i.e total } \\
\text { Cost (TC) }\end{array}$ & 57,210 & $\mathrm{TC}=\mathrm{S}_{\mathrm{i}}=\mathrm{MUC}_{\mathrm{i}}+\mathrm{CFC}_{\mathrm{i}}+\mathrm{IEC}_{\mathrm{b}}$ \\
\hline
\end{tabular}
by Equation (24). A random number $r$ is generated in the range of $0<\mathrm{r}<1$ and if $\mathrm{r}$ is less than acceptance probability

Table 10. Fitness evaluation for string $\mathrm{SA}_{\mathrm{i}}$.

Table 9. Operation assignment for $\mathrm{SA}_{\mathrm{i}}$ string.

\begin{tabular}{lcccccccccc}
\hline Operation $\left(\mathrm{O}_{\text {ik }}\right)$ & $\mathrm{O}_{11}$ & $\mathrm{O}_{13}$ & $\mathrm{O}_{21}$ & $\mathrm{O}_{23}$ & $\mathrm{O}_{31}$ & $\mathrm{O}_{42}$ & $\mathrm{O}_{43}$ & $\mathrm{O}_{51}$ & $\mathrm{O}_{53}$ & $\mathrm{O}_{62}$ \\
\hline Machine no. jik (cell no. c) & $3(1)$ & $5(1)$ & $5(2)$ & $\underline{6(1)}$ & $6(2)$ & $\underline{6(2)}$ & $5(1)$ & $5(1)$ & $\underline{3(2)}$ & $3(2)$ \\
\hline
\end{tabular}

Underlined and italised jik(c) indicate cross-flow. for Example, $\underline{6(1)}$ is a cross-flow movement 


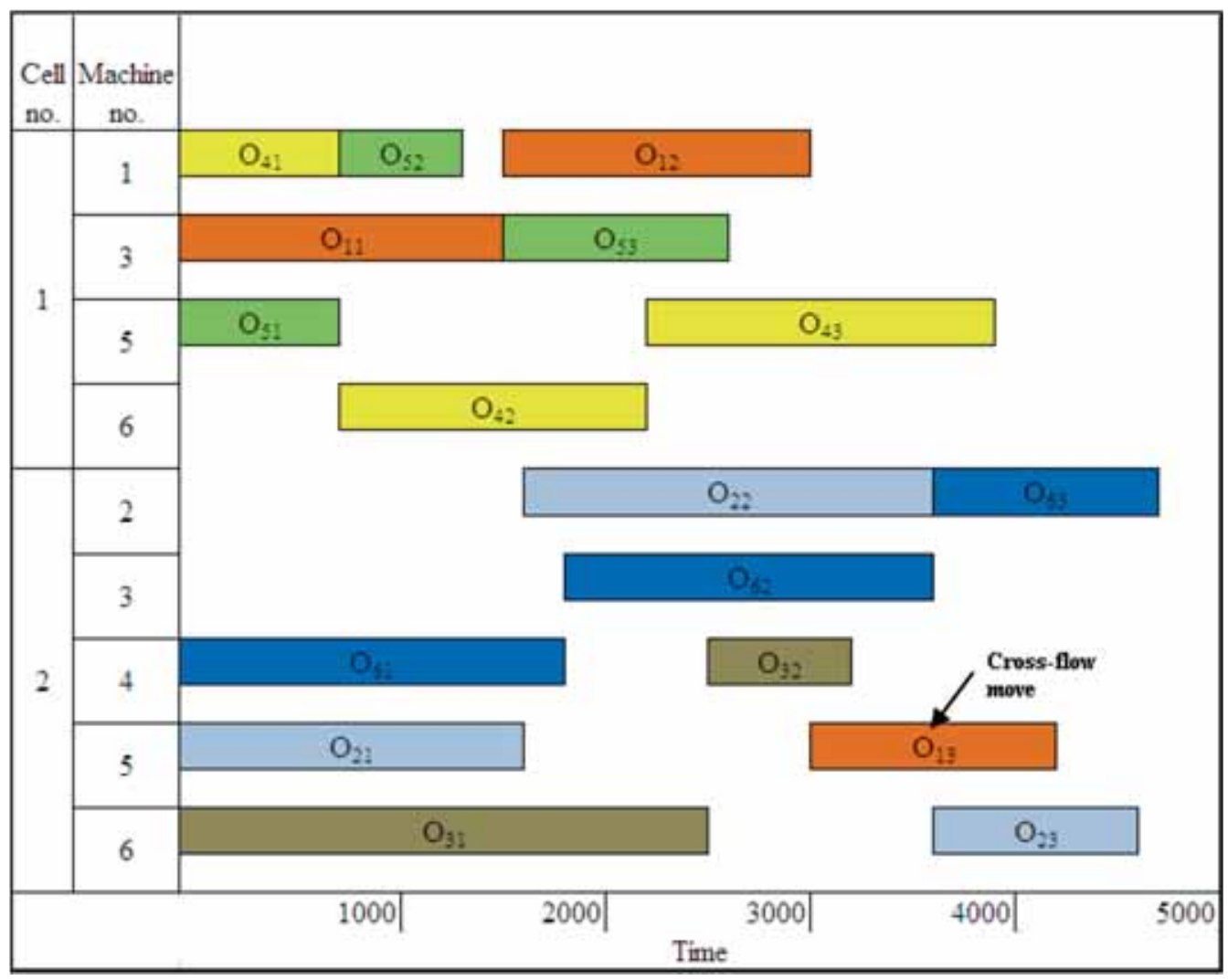

Figure 4. Gantt chart for CF configuration with full machine duplication.

$\left(\mathrm{P}_{\mathrm{r}}\right)$, then the solution is accepted and updated as the current solution for the perturbation in next iteration.

$$
\mathrm{P}_{\mathrm{r}}=\mathrm{e}^{-\frac{\Delta \mathrm{E}}{\mathrm{T}_{\mathrm{i}}}}=\mathrm{e}^{-\frac{\left(\mathrm{S}_{\mathrm{p}}-\mathrm{S}_{\mathrm{i}}\right)}{\mathrm{T}_{\mathrm{i}}}}
$$

Step 8-Cooling schedule: This algorithm uses the most common cooling schedule of geometric rule for temperature reduction and is given in Equation (25).

$$
\mathrm{T}_{\mathrm{i}}=\mathrm{Q}_{\mathrm{R}} \times \mathrm{T}_{\mathrm{i}}
$$

where $\mathrm{Q}_{\mathrm{R}}$ is quenching rate and has the value $0<\mathrm{Q}_{\mathrm{R}}<1$. The literature has reported that $\mathrm{Q}_{\mathrm{R}}$ in the range of $[0.8,0.99]$

Table 11. Fitness evaluation for string $\mathrm{SA}_{\mathrm{p}}$.

\begin{tabular}{lcc}
\hline Cost parameter & Cost & Remarks \\
\hline $\begin{array}{l}\text { Machine utility } \\
\text { cost }\left(\mathrm{MUC}_{\mathrm{i}}\right)\end{array}$ & 51,510 & $\mathrm{MUC}_{\mathrm{i}}=\mathrm{M}_{\mathrm{i}} \times \mathrm{MUR}_{\mathrm{b}}$ \\
$\begin{array}{l}\text { Cross-flow } \\
\text { movement cost }\end{array}$ & $3700 \times 10.1)$ & $\mathrm{O}_{42}, \mathrm{O}_{53}$ has cross-flow movement \\
$(\mathrm{CFC})$ & & $(250 \times 10+120 \times 10)$ \\
$\begin{array}{l}\text { Exceptional } \\
\text { element inter- } \\
\text { cell movement } \\
\text { cost (IEC })\end{array}$ & 0 & No exceptional element movement \\
objective function & 55,210 & $\mathrm{TC}=\mathrm{S}_{\mathrm{p}}=\mathrm{MUC}_{\mathrm{i}}+\mathrm{CFC}_{\mathrm{i}}+\mathrm{IEC}_{\mathrm{b}}$ \\
$\begin{array}{l}\mathrm{S}_{\mathrm{p}} / \text { total cost } \\
(\mathrm{TC})\end{array}$ & & \\
\hline
\end{tabular}

would provide good results [46]. Thus, $\mathrm{Q}_{\mathrm{R}}$ is taken as 0.9 in this approach.

Step 9 - Termination criterion: The final temperature value $\left(\mathrm{T}_{\mathrm{f}}\right)$ is taken as the stopping criterion in the proposed algorithm. Thus, the search process proceeds until the current temperature $\left(T_{i}\right)$ is above the final temperature $\left(T_{f}\right)$.

Step 9 - Output results: After the termination criteria is met, $\mathrm{S}_{\mathrm{g}}$ and $\mathrm{sch}_{\mathrm{g}}$ are given as an optimal solution. Table 12 shows the optimal cost parameters for the CF configuration with full exceptional machine duplications. Figure 4 shows Gantt chart of the optimal schedule for the CF configuration. The optimal makespan time is found to be 4680 and there is no exceptional element inter-cellular movement as all the exceptional machines are duplicated. It is to be noted

Table 12. Optimal cost for CF configuration with full machine

\begin{tabular}{|c|c|c|}
\hline Cost parameter & Cost & Remarks \\
\hline Machine utility cost (MUC) & 47,248 & $\begin{array}{c}\text { Makespan time } \times \text { MUR } \\
(4680 \times 10.1)\end{array}$ \\
\hline $\begin{array}{l}\text { Cross-flow movement cost } \\
\text { (CFC) }\end{array}$ & 1500 & $\begin{array}{l}\mathrm{O}_{13} \text { has cross-flow } \\
\text { movement }(150 \times 10)\end{array}$ \\
\hline $\begin{array}{l}\text { Exceptional element inter- } \\
\text { cell movement cost (IEC) }\end{array}$ & 0 & $\begin{array}{c}\text { No exceptional element } \\
\text { inter-cellular } \\
\text { movement }\end{array}$ \\
\hline Total cost (TC) & 48,748 & $\begin{array}{c}\mathrm{TC}= \\
\mathrm{MUC}+\mathrm{CFC}+\mathrm{IEC}\end{array}$ \\
\hline
\end{tabular}
duplication. 
Table 13. Results for alternate CF configurations of example problem.

\begin{tabular}{|c|c|c|c|c|c|c|c|}
\hline $\mathrm{b}$ & $\begin{array}{l}\text { Duplicated } \\
\text { machine no. } \\
\text { (cell no.) }\end{array}$ & $\begin{array}{l}(1) \\
\text { Makespan } \\
\text { time }\end{array}$ & $\begin{array}{c}(2) \\
\text { Machine } \\
\text { utility } \\
\text { rate } \\
\text { (MUR) }\end{array}$ & $\begin{array}{l}\text { (3) } \\
\text { Machine utility } \\
\text { cost (MUC) } \\
(1) \times(2)\end{array}$ & $\begin{array}{l}(4) \\
\text { Cross-flow } \\
\text { movement } \\
\text { cost }(\mathrm{CFC})\end{array}$ & $\begin{array}{l}\text { (5) } \\
\text { Exceptional element } \\
\text { inter-cell movement } \\
\text { cost (IEC) }\end{array}$ & $\begin{array}{c}(6) \\
\text { Total Cost (TC) } \\
(6)=(3)+(4)+(5)\end{array}$ \\
\hline 1 & $6(1), 5(2), 3(2)$ & 4680 & 10.1 & 47268 & 1500 & 0 & 48768 \\
\hline 2 & $6(1), 5(2)$ & 4680 & 8.6 & 40248 & 1500 & 1800 & 43548 \\
\hline 3 & $6(1), 3(2)$ & 5100 & 9.6 & 48960 & 0 & 2000 & 50960 \\
\hline 4 & $5(2), 3(2)$ & 5650 & 9.3 & 52545 & 0 & 1500 & 54045 \\
\hline 5 & $6(1)$ & 5100 & 8.1 & 41310 & 0 & 3800 & 45110 \\
\hline 6 & $5(2)$ & 5650 & 7.8 & 44070 & 0 & 3300 & 47370 \\
\hline 7 & $3(2)$ & 5650 & 8.8 & 49720 & 0 & 3500 & 53220 \\
\hline 8 & $\begin{array}{l}\text { No machine } \\
\text { duplications }\end{array}$ & 5650 & 7.3 & 41245 & 0 & 5300 & 46545 \\
\hline
\end{tabular}

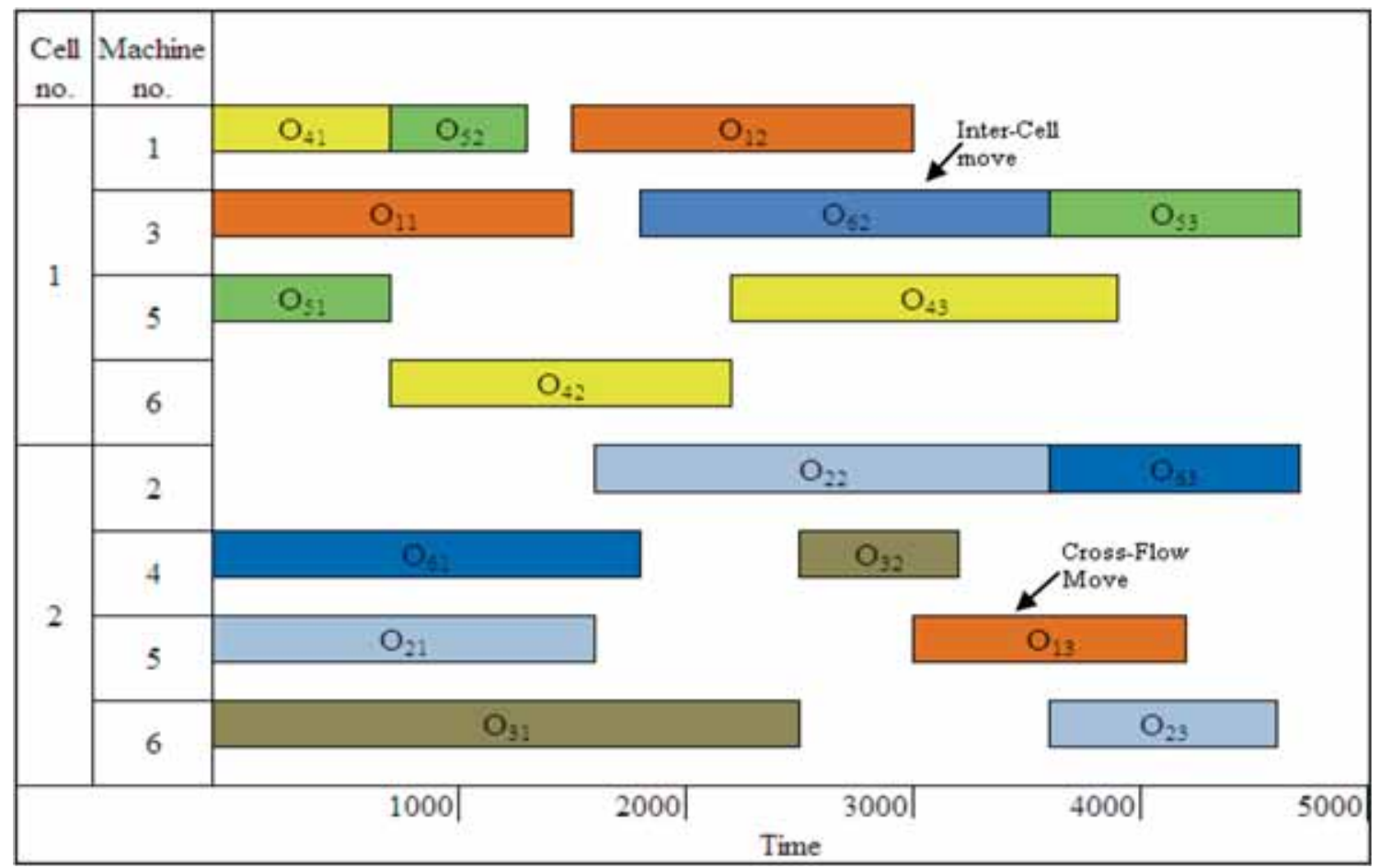

Figure 5. Gantt chart of schedule for Optimal CF configuration.

from figure 4 that the operation $\mathrm{O}_{13}$ is assigned with crossflow as even though machine 5 available in cell 1 to which part 1 is assigned. It is also to be noted that if this cross-flow not allowed, make-span time is increased further.

\subsection{Termination module}

In the termination module, the proposed heuristic approach checks for the termination criteria of whether all ' $\mathrm{B}$ ' $\mathrm{CF}$ configurations are evaluated. Thus, the evaluation module is repeated for all ' $\mathrm{B}$ ' $\mathrm{CF}$ configurations developed in alternative machine cell formation module.

\subsection{Output module}

The best machine cell configuration with the minimum total cost (TC) is found after sorting all ' $\mathrm{B}$ ' $\mathrm{CF}$ configurations based on total cost (TC). Table 13 gives results for each ' $b$ ' $\mathrm{CF}$ configuration.

The results in table 13 indicates that the optimal machine cell configuration with minimum TC is partial machine 
Table 14. Literature problem and input data.

\begin{tabular}{|c|c|c|c|c|c|c|c|c|c|c|}
\hline \multirow[b]{2}{*}{$\begin{array}{l}\text { Pro } \\
\text { blem } \\
\text { No. }\end{array}$} & \multirow[b]{2}{*}{$\begin{array}{l}\text { Problem } \\
\text { source }\end{array}$} & \multicolumn{6}{|c|}{ Problem Size } & \multirow[b]{2}{*}{$\begin{array}{c}\text { Part } \\
\text { processing } \\
\text { data }\end{array}$} & \multicolumn{2}{|c|}{ Cost co-efficients data } \\
\hline & & $\begin{array}{c}\text { Parts } \\
\mathrm{n}\end{array}$ & $\begin{array}{c}\text { Machines } \\
\text { m }\end{array}$ & $\begin{array}{c}\text { Cells } \\
\text { C }\end{array}$ & $\sum_{i=1}^{n} K i$ & $\begin{array}{c}\text { No. of } \\
\text { Decision } \\
\text { Variables }\end{array}$ & $\begin{array}{l}\text { No. of } \\
\text { Cons } \\
\text { traints }\end{array}$ & & $\begin{array}{c}\text { Machine } \\
\text { utility rate } \\
\mathrm{MU}_{\mathrm{j}}\end{array}$ & $\begin{array}{c}\text { Inter-cell } \\
\text { cost } \\
\mathrm{IC}_{\mathrm{c}^{\prime} \mathrm{c}} / \mathrm{CF}_{\mathrm{c}^{\prime} \mathrm{c}}\end{array}$ \\
\hline 1 & $\begin{array}{c}\text { Liang and } \\
\text { Zolfaghari } \\
{[40]}\end{array}$ & 4 & 4 & 2 & 12 & 60 & 216 & Table A.1a & Table A.1b & Table A.1c \\
\hline 2 & $\begin{array}{c}\text { Arkat et al } \\
\text { [12] }\end{array}$ & 5 & 4 & 2 & 12 & 62 & 222 & Table A.2a & Table A.2b & Table A.2c \\
\hline 3 & $\begin{array}{c}\text { Mak et al } \\
{[48]}\end{array}$ & 7 & 6 & 2 & 15 & 83 & 298 & Table A.3a & Table A.3b & Table A.3c \\
\hline 4 & $\begin{array}{c}\text { James et al } \\
\text { [49] }\end{array}$ & 8 & 6 & 2 & 22 & 106 & 420 & Table A.4a & Table A.4b & Table A.4c \\
\hline 5 & $\begin{array}{l}\text { Albadawi } \\
\text { et al [50] }\end{array}$ & 10 & 12 & 3 & 39 & 258 & 1269 & Table A.5a & Table A.5b & Table A.5c \\
\hline 6 & $\begin{array}{c}\text { Chang et al } \\
\text { [35] }\end{array}$ & 10 & 10 & 3 & 32 & 218 & 1180 & Table A.6a & Table A.6b & Table A.6c \\
\hline 7 & $\begin{array}{c}\text { James } \text { et al } \\
{[49]}\end{array}$ & 11 & 7 & 4 & 21 & 159 & 865 & Table A.7a & Table A.7b & Table A.7c \\
\hline 8 & $\begin{array}{c}\text { James et al } \\
{[49]}\end{array}$ & 10 & 10 & 5 & 24 & 294 & 1898 & Table A.8a & Table A.8b & Table A.8c \\
\hline 9 & $\begin{array}{l}\text { Harhalakis } \\
\text { et al [51] }\end{array}$ & 20 & 17 & 4 & 78 & 606 & 4601 & Table A.9a & Table A.9b & Table A.9c \\
\hline 10 & $\begin{array}{l}\text { Albadawi } \\
\text { et al [50] }\end{array}$ & 24 & 14 & 4 & 61 & 513 & 4172 & Table A.10a & Table A.10b & Table A.10c \\
\hline 11 & $\begin{array}{c}\text { James et al } \\
{[49]}\end{array}$ & 35 & 20 & 5 & 136 & 1191 & 12512 & Table A.11a & Table A.11b & Table A.11c \\
\hline 12 & $\begin{array}{c}\text { James et al } \\
{[49]}\end{array}$ & 40 & 24 & 7 & 130 & 1664 & 22105 & Table A.12a & Table A.12b & Table A.12c \\
\hline
\end{tabular}

n, m, C, $\sum_{i=1}^{n} K i$ represents number of parts, number of machines, number of cells, number of operations respectively.

All tables A.1a - A.12c are given in Appendix.

duplication of machine 5 in cell 1 and machine 6 in cell 2. It is seen from table 13 that the machine duplications reduces makespan time and thus compensates increased total machine utility rate. It is also noted that cross-flow is preferred only when it reduces makespan and compensates the increase in cross-flow cost. Figure 5 shows the schedule for optimal CF configuration. It is seen from figure 5 that operation $\mathrm{O}_{13}$ has cross-flow, inter-cell movement for operation $\mathrm{O}_{62}$ and optimal makespan time is 4680 .

\section{Performance study}

The proposed heuristic procedure with the alternate configurations for a particular part-machine incidence matrix is programmed in MATLAB and implemented on HP dx2280 MT model X86 based PC. Table 14 shows the input data of part processing data (Tables A1a-A12a) and cost coefficients like machine utility rate per unit time $M U_{j}$ (Tables $\mathrm{A} 1 \mathrm{~b}-\mathrm{A} 12 \mathrm{~b}$ ), inter-cell $I C_{c^{\prime} c}$ and cross-flow movement cost per unit $C F_{c^{\prime} c}$ (Tables A1c-A12c) and the problem size of the test problems taken from literature. The part-machine incidence matrix indicating the CF stage of the CMS design is adopted as given in literature and the processing characteristics of the processing sequence, processing time and demand $\left(d_{i}\right)$ of the parts are generated for the problems for which such data are not available. The problems are solved using the proposed heuristic approach and mathematical approach by ILOG CPLEX solver (12.6 academic edition) with the branch limits of $10^{7}$ and $10^{8}$. Table 15 shows the optimal CF solution for literature source data (i.e., without machine duplication), heuristic and mathematical approaches with its cost components for each problem. Besides, the solutions of the approaches are compared in terms of relative percentage of deviation (RPD) of a solution from the best CF solution $\left(\mathrm{TC}_{\text {best }}\right)$, given by Equation (26). Table 16 gives the comparison of CF solutions in terms of total cost of operation (TC), RPD and computational time. The $\mathrm{TC}_{\text {best }}$ is shown in bold format in table 16.

$$
\mathrm{RPD}=\frac{\mathrm{TC}-\mathrm{TC}_{\mathrm{best}}}{\mathrm{TC}_{\text {best }}}
$$




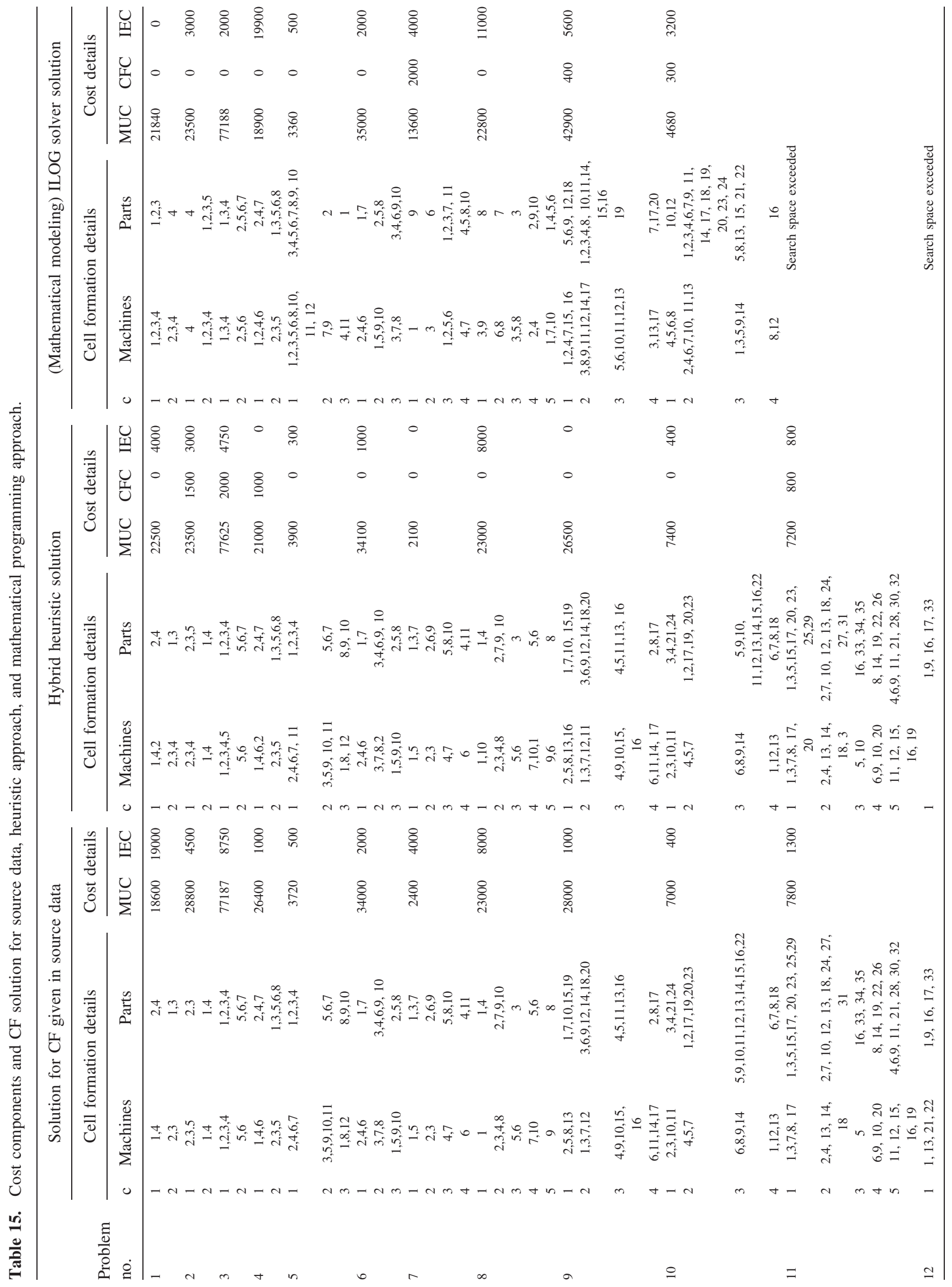


The results shown in table 15 reveal that the integrated $\mathrm{CF}$ and scheduling decisions with cross-flow have resulted in the minimized operational cost of CMS. The comparison of CF solutions in terms of RPD (shown in table 16) reveals the following:

- CPLEX gives the best solution to the problems 1-4, the problems those with the number of decision variables and constraints are less than 100 and 500, respectively.

- When the number of variables is around 200-300, and the number of constraints are between 1000 and 2000 (problems 5-8), mixed responses are witnessed.

- The proposed heuristic provides better solutions than CPLEX solutions to the problems 9 and 10, where the number of decision variables is in the order of 500 and the number of constraints is around 500 and 4000, respectively.

- When the number of decision variables and constraints are greater than 1000 and 10000 (problem 11 and 12), CPLEX does not produce any results stating 'search space exceeded', whereas the proposed HH is capable of providing solutions.

Further, the computational time of CPLEX shows an exponential increase in the computational study and not able to provide a solution at all for larger problems (problems 11and 12). The lesser computational time experienced with the heuristic, compared to CPLEX solver, is owing to the reduced search space resulted due to the fixation of the part and machine assignment and machine duplications to exceptional elements. Though the problem is solved in the design phase for which computational time is least important, the solution approach has to produce near-optimal solutions to the problem that has problem sizes of real manufacturing scenario. Thus, it can be concluded that the proposed $\mathrm{HH}$ is computationally efficient and can be useful to find solutions closer to optimal for the problems of the dimension of 500 decision variables and 1000 constraints, which is the case with most of the industrial cases. CPLEX can be used for the smaller size problems (i.e., the number of decision variables less than 500) due to lesser search space.

\section{Model validity}

The model features are validated by studying the effect of integration, machine duplication, and association of scheduling and cross-flow.

\subsection{Effect of integration}

The proposed CMS design model integrates the structural design issue decisions of cell formation with operational 
issue decisions of scheduling under machine duplication and cross-flow considerations. The proposed objective criterion uses the new cost parameter of machine utility cost (MUC) to integrate CF and scheduling. The MUC justifies the feasibility of machine duplication. The effect of integration is studied by comparing the objective criterion of the following cases:

- The operational cost of the CF decisions (i.e., part and machine assignment decisions) as given in source literature problems is shown in table 14. As these literature problems do not have associated scheduling, the optimal schedule decisions are generated using SAA-GA module of HH. Further, these problems have not considered machine duplications and hence, have no cross-flow facilitations. These make model be without machine duplication and cross-flow. The objective values of this model (i.e., without machine duplication and cross-flow) are given as 'source data total cost (TC)' values in table 16.

- The minimum operational cost of each problem given in table 14 evolved by optimizing the CF configuration considering machine duplication strategy along with the association of scheduling under cross-flow considerations. Thus, the proposed model is with machine duplication and cross-flow facilitation. The best cost solutions are given by either proposed $\mathrm{HH}$ solutions or ILOG CPLEX solver and are shown in table 16 (shown as bold font).

Figure 6 shows the comparison of the proposed model's best objective values with objective values for literature $\mathrm{CF}$ decisions. This comparison reveals that the inclusion of scheduling under machine duplication and cross-flow environments could evolve optimized minimum cost

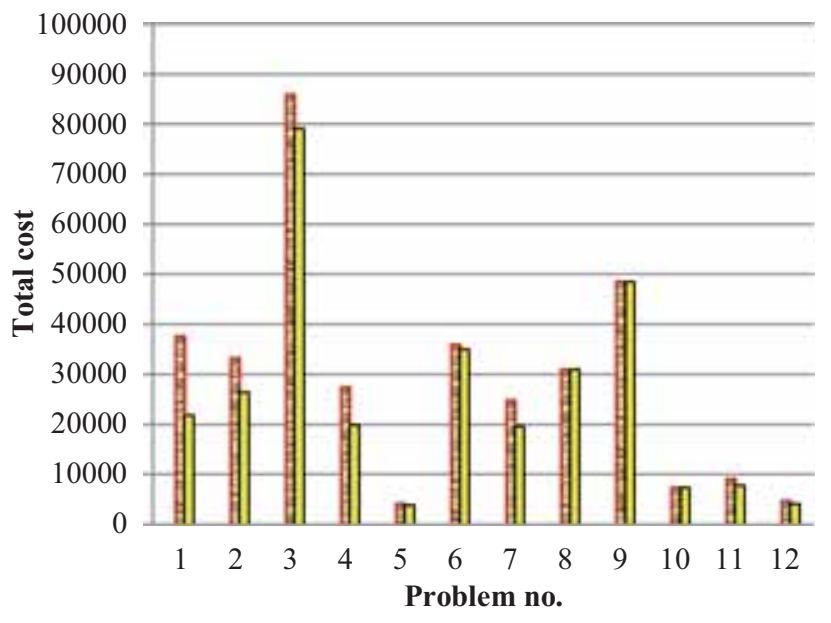

⿴囗十 Without machine duplications and cross-flow $\square$ With machine duplications and cross-flow

Figure 6. Comparison of literature grouping data with the proposed model grouping.

grouping and operation assignment decisions. This proves that integration brings forth the effective realization of CMS advantages. Further, the simultaneous approach of design and operational decisions enable designers to design better performing efficient and effective cells.

\subsection{Effect of association of scheduling and cross- flow}

The proposed model allows cross-flow inter-cell movement under machine duplication environment. This cross-flow improves scheduling flexibility, reduces makespan and

Table 16. Comparison of the CF solutions.

\begin{tabular}{|c|c|c|c|c|c|c|c|c|c|c|}
\hline \multirow{3}{*}{$\begin{array}{l}\text { Pro } \\
\text { blem } \\
\text { no. }\end{array}$} & \multicolumn{4}{|c|}{ Total Cost (TC) } & \multicolumn{3}{|c|}{$\begin{array}{l}\text { Solution comparison with Best } \\
\text { (RPD) in } \%\end{array}$} & \multicolumn{3}{|c|}{ Computational time (in s) } \\
\hline & \multirow[b]{2}{*}{$\begin{array}{l}\text { Source } \\
\text { data }\end{array}$} & \multirow{2}{*}{$\begin{array}{c}\text { Proposed } \\
\text { heuristic SAA- } \\
\text { GA }\end{array}$} & \multicolumn{2}{|c|}{ ILOG CPLEX } & \multirow{2}{*}{$\begin{array}{c}\text { Source } \\
\text { data }\end{array}$} & \multirow{2}{*}{$\begin{array}{c}\text { Proposed } \\
\text { hybrid } \\
\text { heuristic }\end{array}$} & \multirow[b]{2}{*}{$\begin{array}{l}\text { ILOG } \\
\text { CPLEX }\end{array}$} & \multirow{2}{*}{$\begin{array}{l}\text { Proposed } \\
\text { hybrid } \\
\text { heuristic }\end{array}$} & \multicolumn{2}{|c|}{ ILOG CPLEX } \\
\hline & & & $* \times 10^{7}$ & $* \times 10^{8}$ & & & & & $* \times 10^{7}$ & $* \times 10^{8}$ \\
\hline 1 & 37600 & 26500 & 21840 & 21840 & 72 & 21 & 0 & 5 & 32 & 32 \\
\hline 2 & 33300 & 28000 & 26500 & 26500 & 26 & 6 & 0 & 18 & 21 & 21 \\
\hline 3 & 85937 & 84375 & 79188 & 79188 & 9 & 7 & 0 & 42 & 74 & 74 \\
\hline 4 & 27400 & 22000 & 19900 & 19900 & 38 & 11 & 0 & 45 & 70 & 70 \\
\hline 5 & 4220 & 4200 & 4680 & 3860 & 9 & 9 & 0 & 25 & 272 & 11664 \\
\hline 6 & 36000 & 35100 & 40000 & 37000 & 3 & 0 & 5 & 48 & 542 & 15804 \\
\hline 7 & 24800 & 20900 & 22200 & 19600 & 26 & 6 & 0 & 50 & 791 & 18936 \\
\hline 8 & 31000 & 31000 & 33800 & 33800 & 0 & 0 & 9 & 56 & 503 & 16668 \\
\hline 9 & 48600 & 48600 & 50900 & 48900 & 0 & 0 & 1 & 614 & 1962 & 30672 \\
\hline 10 & 7400 & 7400 & 8760 & 8180 & 0 & 0 & 10 & 36 & 924 & 27108 \\
\hline 11 & 9100 & 7900 & Searcl & space & 15 & 0 & - & 29.2 hours & - & - \\
\hline 12 & 4740 & 4200 & exc & eeded & 13 & 0 & - & 42.5 hours & - & - \\
\hline
\end{tabular}

*Represents branch limit value of 2.14748364 
hence reduces operating cost. Hence, cross-flow increases machine utilization and can justify added machine investment due to machine duplication. This altogether results in better performing cells that have minimum operating cost. The effect of cross-flow movement is studied by evaluating the optimal operation assignment decisions given in figure 5. Figure 7 shows the optimal schedule for CMS environment with machine duplication and no cross-flow. The cross-flow operation $\mathrm{O}_{13}$ that is assigned to machine 5 in cell 2 is shifted to machine 5 in cell 1 as shown in figure 7 . It is noted that shifting of cross-flow operation $\mathrm{O}_{13}$ results in the increase of makespan from 4680 to 5100 and leads to increased operating cost. This reveals that association of scheduling and cross-flow gives cost advantageous optimal decisions.

\subsection{Effect of machine duplication}

The model considers machine duplication and allows duplication only in other cells. This strategy is studied by evaluating the example problem considering the machine

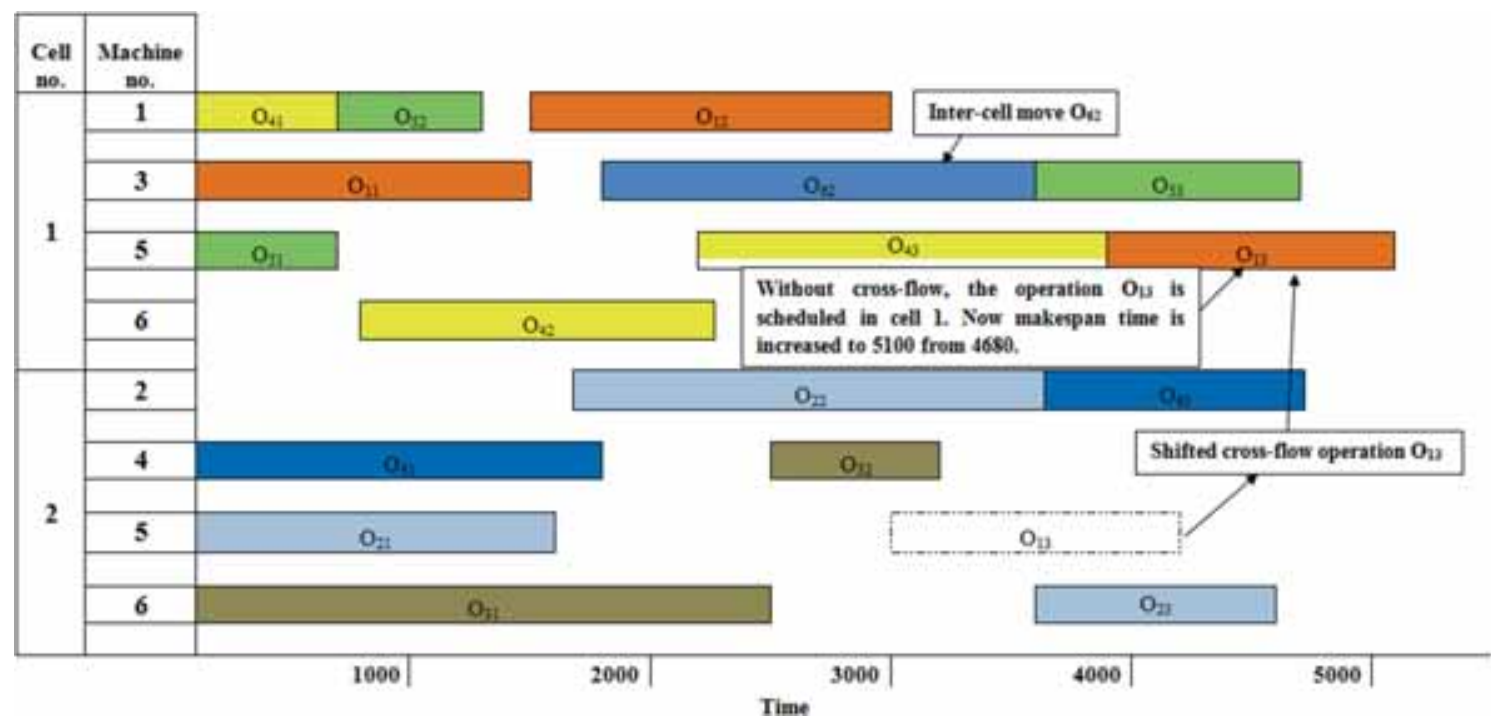

Figure 7. Optimal CF and scheduling with no cross-flow considerations.

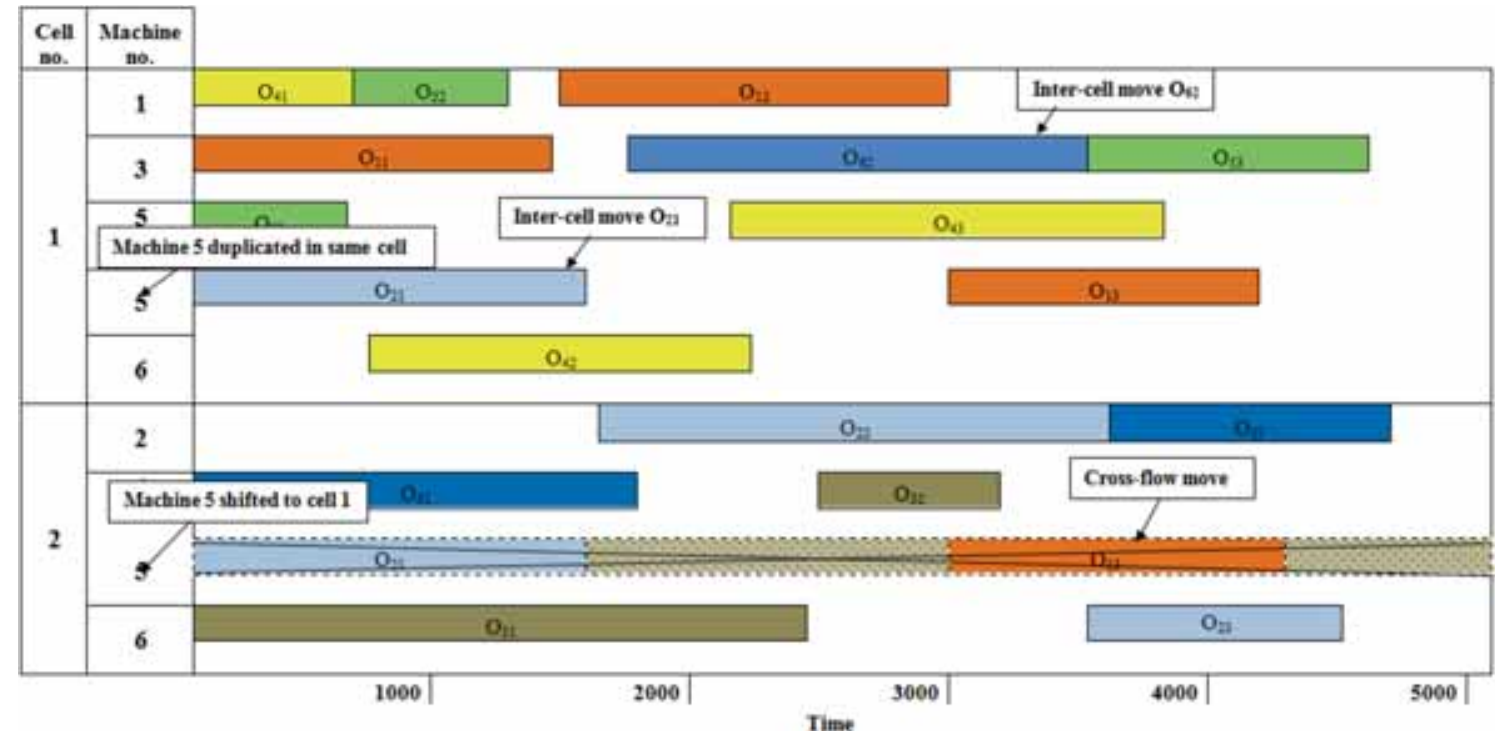

Figure 8. Optimal decisions when machine duplication allowed in the same cell. 
Table 17. Cost comparison for different CMS environment cases.

\begin{tabular}{|c|c|c|c|c|c|c|c|}
\hline Sl.No. & Cases & $\begin{array}{l}(1) \\
\text { Makespan } \\
\text { time }\end{array}$ & $\begin{array}{c}(2) \\
\text { Machine } \\
\text { utility } \\
\text { rate } \\
\text { (MUR) }\end{array}$ & $\begin{array}{c}(3) \\
\text { Machine } \\
\text { utility cost } \\
(\text { MUC) } \\
(1) \times(2)\end{array}$ & $\begin{array}{l}(4) \\
\text { Cross-flow } \\
\text { movement } \\
\text { cost }(\mathrm{CFC})\end{array}$ & $\begin{array}{l}\quad(5) \\
\text { Exceptional } \\
\text { element inter- } \\
\text { cell movement } \\
\text { cost (IEC) }\end{array}$ & $\begin{array}{c}(6) \\
\text { Total Cost }(\mathrm{TC}) \\
(6)=(3)+(4)+(5)\end{array}$ \\
\hline 1 & $\begin{array}{l}\text { With no machine } \\
\text { duplication and no } \\
\text { cross-flow }\end{array}$ & 5650 & 7.3 & 41245 & 0 & 5300 & 46545 \\
\hline 2 & $\begin{array}{c}\text { With machine duplication } \\
\text { in other cell and no } \\
\text { cross-flow (Figure } 7 \text { ) }\end{array}$ & 5100 & 8.6 & 43860 & 0 & 1800 & 45660 \\
\hline 3 & $\begin{array}{l}\text { With machine duplication } \\
\text { in the same cell and no } \\
\text { cross-flow (Figure } 8 \text { ) }\end{array}$ & 4680 & 8.6 & 40248 & 0 & $1800+2000$ & 44048 \\
\hline 4 & $\begin{array}{l}\text { With machine duplication } \\
\text { and cross-flow } \\
\text { (Figure 5) }\end{array}$ & 4680 & 8.6 & 40248 & 1500 & 1800 & 43548 \\
\hline
\end{tabular}

duplication in the same cell and is compared with the operating cost of the optimal configuration shown in figure 5. Figure 8 shows the schedule for $\mathrm{CF}$ configuration with machine 5 being duplicated in the same cell of cell 1 . It is seen that shifting machine number 5 from cell 2 to cell 1 makes the operation $\mathrm{O}_{21}$ as inter-cell move and raises inter-cell move cost. However, the cross-flow move of operation $\mathrm{O}_{13}$ is eliminated. But even though cross-flow is avoided, the inter-cell move cost is comparatively more in this case and hence leads to an increase in operating cost. However, these comparisons are data dependent and hence future research has to consider machine duplication in the same or other cells.

\subsection{Discussions}

Table 17 consolidates the cost comparison of various CMS environment cases discussed above. The cases considered are with and without machine duplication, machine duplication in same and other cell and with and without crossflow. The comparison of the four cases shown in table 17 reveals that:

- The machine duplication even though increases machine investment cost (i.e., here MUR increased from 7.3 to 8.6 for cases of without and with machine duplication, respectively as shown in table 17), the additional cost can be justified by reduced makespan time (i.e., reduced from 5650 to 5100) and reduced inter-cell movement cost (i.e., reduced from 5300 to 1800). Altogether, the operating cost is reduced from 46545 to 45660 .

- The comparison of cases 2 and 4 (shown in table 17) that consider no cross-flow (i.e., case 2) and cross-flow considerations reveals that cross-flow reduces the makespan time from 5100 to 4680 and reduces operating cost from 45660 to 43548 . Thus, cross-flow gives scheduling flexibility, enhances machine utilization, justifies machine duplication and finally reduces the cost of operation of CMS.

- On considering cases 3 and 4 of table 17 which deal with machine duplication in same cell (case no. 3) and machine duplication in other cell (case no. 4), it is seen that for this example problem there is an increase in inter-cell movement cost from 1800 to 3800 and hence increase in cost of operation. However, this comparison is data dependent.

The above discussions on model validity can be summarized as follows:

- The model evolves cost advantageous decisions of integrated CF and scheduling.

- Machine duplications are done only when the additional machine investment cost is lesser than machine utility cost and inter-cell cost.

- The cross-flow facilitates routing flexibility and reduces operating cost.

Thus, the proposed model is a better representation of a practical CMS manufacturing environment. The model assists the designers to design efficient and effective cells.

\section{Conclusions}

In this paper, a CMS design model integrating design and operational issues is proposed. A cell formation (CF) model is developed based on cell scheduling (CS) of part operations. The model is facilitated with machine duplications and enhances scheduling flexibility by permitting crossflow. The proposed integrated approach is vital for a CMS design to represent the practical CMS environment. The 
model is mathematically formulated with the objective of minimizing total cost of operation (TC) which comprises of machine utility cost and two types of inter-cell costs namely cross-flow inter-cell movement cost and exceptional element inter-cell movement cost.

A hybrid heuristic $(\mathrm{HH})$ that includes SAA embedded with GA scheduler is proposed and illustrated with an example. The HH identifies exceptional elements (EE) for a cell grouping and develops alternate machine cell configurations. The $\mathrm{HH}$ analyses each alternate configurations by using SAA which optimizes operation assignment considering alternate machine routings and GA which generates the optimal schedule for operation assignment decisions by SAA. The computational analysis is done with 12 literature problems that are solved using the proposed $\mathrm{HH}$ and CPLEX mathematical programming solver. From the comparisons of $\mathrm{HH}$ and CPLEX solutions in terms of relative percentage of deviation (RPD) and computational time, it is concluded that the proposed $\mathrm{HH}$ is computationally efficient and able to find solution closer to optimal for large-sized problems (in the dimension of 500 decision variables and 1000 constraints). The computational capability of HH is due to reduced search space for large-sized problems caused by fixing part and machine assignment and analyzing only machine duplications of exceptional elements.

The model features of integrated CF and CS decisions under machine duplications and cross-flow are compared with the grouping decisions of literature problem with the strategy of no machine duplications. The comparison reveals that the proposed model could evolve better cell grouping decisions. Thus it can be inferred that the proposed model identifies cost advantageous decisions and thus provides an improved CMS design that has minimized operational cost.

The heuristic algorithm efficiency is limited by the method adopted for part-machine grouping and for scheduling. The heuristic approach is relevant when partmachine grouping has limited EE and hence grouping has computable alternate machine cell configurations. In future research, meta-heuristics can be used for part and machine assignment decisions to improve the computational efficiency of larger size problems. The other algorithms hybridization like SAA and PSO, GA and PSO are to be evaluated for improved computation. The model can be extended by allowing machine duplications to have more than one machine-type in each cell, considering intra-cell movement cost and lot splitting.

\section{List of symbols}

\section{Indices}

$\mathrm{c}, \mathrm{c}^{\prime} \quad$ index for cell $\left(\mathrm{c}, \mathrm{c}^{\prime}=1,2, \ldots, \mathrm{C}\right)$

$\mathrm{i}, \mathrm{p} \quad$ index for parts $(\mathrm{i}=1,2, \ldots, \mathrm{n})$ $\mathrm{j} \quad$ index for machines $(\mathrm{j}=1,2, \ldots, \mathrm{m})$

$\mathrm{k}, \mathrm{q}$ index for part processing sequence $\left(\mathrm{k}=1,2, \ldots, \mathrm{K}_{\mathrm{i}}\right)$

\section{Model parameters}

$\mathrm{C}$ number of cells

$\mathrm{C}_{\mathrm{iK}_{\mathrm{i}}} \quad$ completion time of the last $\left(\mathrm{K}_{\mathrm{i}}^{\mathrm{th}}\right)$ operation $\mathrm{O}_{\mathrm{iK}_{\mathrm{i}}}$

$\mathrm{C}_{\mathrm{ik}} \quad$ completion time of the operation $\mathrm{O}_{\mathrm{ik}}$

$\mathrm{C}_{\max }$ makespan time of the schedule

$\mathrm{CF}_{\mathrm{c}^{\prime} \mathrm{c}}$ cross-flow inter-cell movement cost per unit part from cell ' $\mathrm{c}$ ' to cell ' $\mathrm{c}$ '

CFC cross-flow inter-cell movement cost

$d_{i} \quad$ demand for part ' $i$ ' per period

$\mathrm{EF}_{\mathrm{c}^{\prime} \mathrm{c}}$ exceptional element inter-cell movement cost per unit part from cell ' $c$ ' to cell ' $c$ '

$\mathrm{IC}_{\mathrm{c}^{\prime} \mathrm{c}} \quad$ inter-cell movement cost per unit part from cell ' $\mathrm{c}$ ', to cell ' $c$ '

ICC inter-cell movement cost

IEC exceptional element inter-cell movement cost

$\mathrm{j}_{\mathrm{ik}} \quad$ machine ' $\mathrm{j}$ ' required for the operation $\mathrm{O}_{\mathrm{ik}}$

$\mathrm{K}_{\mathrm{i}} \quad$ number of operations of part ' $\mathrm{i}$ '

$\mathrm{n}$ number of parts

$\mathrm{m} \quad$ number of machines

$\mathrm{MU}_{\mathrm{j}} \quad$ utility rate of machine-type 'j' per unit time

MUC machine utility cost

MUR total machine utility rate

$\mathrm{O}_{\mathrm{ik}} \quad \mathrm{k}^{\text {th }}$ operation of part ' $\mathrm{i}$ '

$\mathrm{S}_{\mathrm{ik}} \quad$ start time of operation $\mathrm{O}_{\mathrm{ik}}$

$t_{i k} \quad$ processing time for operation $\mathrm{O}_{\mathrm{ik}}$

TC total cost of operation

\section{Model variables}

$\mathrm{X}_{\mathrm{j} . \mathrm{c}} \quad$ binary integer variable that indicates the assignment of machine ' $\mathrm{j}$ ' to cell ' $\mathrm{c}$ '

$\mathrm{Y}_{\mathrm{ik} . \mathrm{c}} \quad$ binary integer variable that indicates operation $\mathrm{O}_{\mathrm{ik}}$ is assigned to cell ' $c$ '

$\mathrm{Z}_{\mathrm{i.c}} \quad$ binary integer variable that indicates the assignment of part ' $\mathrm{i}$ ' to cell 'c'

$\mathrm{A}_{\mathrm{ikpq.c}}$ binary integer variable that indicates the precedence relationship of operations $\mathrm{O}_{\mathrm{ik}}$ and $\mathrm{O}_{\mathrm{pq}}$ assigned to cell ' $c$ '

\section{Hybrid heuristic SAA-GA variables and parameters}

$\Delta \mathrm{E} \quad$ change in entropy

a number of operations with alternate machine choices for a cell configuration

b index for machine cell configuration

B number of alternate machine cell configurations for a cell formation

cnt perturbation counter

$\mathrm{CFC}_{\mathrm{i}}$ cross-flow movement cost for SAA string $\mathrm{SA}_{\mathrm{i}}$

$\mathrm{IEC}_{\mathrm{b}}$ exceptional element inter-cell movement cost for machine cell configuration $b$

$\mathrm{IT}_{\max }$ number of iterations per temperature

$\mathrm{M}_{\mathrm{i}} \quad$ minimum makespan time for SAA string $\mathrm{SA}_{\mathrm{i}}$

$\mathrm{MUC}_{\mathrm{i}}$ machine utility cost for SAA string $\mathrm{SA}_{\mathrm{i}}$ 
$\mathrm{MUR}_{\mathrm{b}} \quad$ total machine utility rate for machine cell configuration $b$

$\mathrm{P}_{\mathrm{r}} \quad$ acceptance probability of worst solutions

$\mathrm{Q}_{\mathrm{R}} \quad$ SAA quenching rate

$\mathrm{r} \quad$ random number where $0<\mathrm{r}<1$

$\mathrm{S}_{\mathrm{g}} \quad$ SAA global best solution

$\mathrm{S}_{\mathrm{p}} \quad$ SAA perturbed solution

$\mathrm{S}_{\mathrm{i}} \quad$ SAA solution at any instant

$\mathrm{SA}_{\mathrm{g}} \quad \mathrm{SAA}$ global best string

$\mathrm{SA}_{\mathrm{p}} \quad$ SAA perturbed string

$\mathrm{SA}_{\mathrm{i}} \quad$ SAA string at any instant

$\mathrm{Sch}_{\mathrm{g}} \quad$ best optimal schedule

$\mathrm{sch}_{\mathrm{i}} \quad$ optimal schedule at any instant

$\mathrm{T}_{0} \quad$ SAA initial temperature

$\mathrm{T}_{\mathrm{f}} \quad$ SAA final temperature

$\mathrm{T}_{\mathrm{i}} \quad$ SAA temperature at any instant

\section{References}

[1] Edwards J D 2013 World Product Data Management - Discrete Guide Release A9.3, E21777-04, Copyright (C) 2013, Oracle and/or its affiliates

[2] Askin R G 2013 Contributions to the design and analysis of cellular manufacturing systems. International Journal of Production Research 51:23-24: 6778-6787

[3] Caux C, Bruniaux R and Pierreval H 2000 Cell formation with alternative process plans and machine capacity constraints: A new combined approach. International Journal of Production Economics 64: 279-284

[4] Uddin M K and Shanker K 2002 Grouping of parts and machines in presence of alternative process routes by genetic algorithm. International Journal of Production Economics 76: $219-228$

[5] Brown J R 2015 A capacity constrained mathematical programming model for cellular manufacturing with exceptional elements. Journal of Manufacturing Systems 37/1: 227-232

[6] Papaioannou G and Wilson J M 2010 The evolution of cell formation problem methodologies based on recent studies (1997-2008): Review and directions for future research. European Journal of Operational Research 20: 509-521

[7] Tavakkoli-Moghaddam R, Ranjbar-Bourani M, Amin G R and Siada A 2010 A cell formation problem considering machine utilization and alternative process routes by scatter search. Journal of Intelligent Manufacturing 23/4: 1127-1139

[8] Hassan Zadeh A, Hamid Afshari and Reza Ramazani Khorshid-Doust 2014 Integration of process planning and production planning and control in cellular manufacturing. Production Planning and Control: The Management of Operations 25/10: 840-857

[9] Chattopadhyay M, Sengupta S, Ghosh T, Pranab K Dan and Sitanath Mazumdar 2013 Neuro-genetic impact on cell formation methods of Cellular Manufacturing System design: A quantitative review and analysis. Computers and Industrial Engineering 64: 256-272

[10] Li D, Wang Y, Xiao Guangxue and Tang Jiafu 2013 Dynamic parts scheduling in multiple job shop cells considering intercell moves and flexible routes. Computers and Operations Research 40: 1207-1223

[11] Wemmerlov U and Hyer N L 1986 Procedures for the Part Family/Machine Group Identification Problem in Cellular Manufacturing. Journal of Operations Management 6-2: 125-147

[12] Arkat J, Mehdi Hosseinabadi Farahani and Fardin Ahmadizar 2012 Multi-objective genetic algorithm for cell formation problem considering cellular layout and operations scheduling. International Journal of Computer Integrated Manufacturing 25-7: 625-635

[13] Mak K L, Lau J S K and Wang X X 2005 A genetic scheduling methodology for virtual cellular manufacturing systems: an industrial application. International Journal of Production Research 43-12: 2423-2450

[14] Kesen S E, Das S K and Gung Z 2010 A genetic algorithm based heuristic for scheduling of virtual manufacturing cells (VMCs). Computers and Operations Research 37: $1148-1156$

[15] Jeon G and Leep H R 2006 Forming part families by using the genetic algorithm and designing machine cells under demand changes. Computers and Operations Research 33: 263-283

[16] Egilmez Gokhan and Süer Gürsel 2014 The impact of risk on the integrated cellular design and control. International Journal of Production Research 52(5): 1455-1478

[17] Umit Bilge, Murat Firat and Erinc Albey 2008 A parametric fuzzy logic approach to dynamic part routing under full routing flexibility. Computers and Industrial Engineering 55: $15-33$

[18] Chung S-H, Tai-Hsi Wu and Chin-Chih Chang 2011 An efficient tabu search algorithm to the cell formation problem with alternative routings and machine reliability considerations. Computers and Industrial Engineering 60: $7-15$

[19] Jeon G, Leep H R and Parsaei H R 1998 A cellular manufacturing system based on new similarity coefficient which considers alternative routes during machine failure. Computers and Industrial Engineering 34(1): 21-36

[20] Solimanpur M and Foroughi A 2011 A new approach to the cell formation problem with alternative processing routes and operation sequence. International Journal of Production Research 49(19): 5833-5849

[21] Jayaswal S and Adil G K 2004 Efficient algorithm for cell formation with sequence data, machine replications and alternative process routings. International Journal of Production Research 42(12): 2419-2433

[22] Ming Zhou and Askin R G 1998 Formation of general GT Cells: An Operation based Approach. Computers and Industrial Engineering 34(1): 147-157

[23] Cao D and Chen M 2004 Using penalty function and Tabu search to solve cell formation problems with fixed cell cost. Computers and Operations Research 31: 21-37

[24] Özgüven C, LaleÖzbak and Yasemin Yavuz 2010 Mathematical models for job-shop scheduling problems with routing and process plan flexibility. Applied Mathematical Modelling 34: 1539-1548

[25] Deljoo V, Mirzapour Al-e-hashem S M J, Deljoo F and Aryanezhad M B 2010 Using genetic algorithm to solve dynamic cell formation problem. Applied Mathematical Modeling 34: 1078-1092 
[26] Mahdavi I, Amin Aalaei, Mohammad Mahdi Paydar, and Maghsud Solimanpur 2010 Designing a mathematical model for dynamic cellular manufacturing systems considering production planning and worker assignment. Computers and Mathematics with Applications 60: 1014-1025

[27] Defersha F M and Chen M 2006 A comprehensive mathematical model for the design of cellular manufacturing systems. International Journal of Production Economics 103: 767-783

[28] Mathur K and Süer G A 2013 Math modeling and GA approach to simultaneously make overtime decisions, load cells and sequence products. Computers and Industrial Engineering 66: 614-624

[29] King J R 1980 Machine-component grouping in production flow analysis: an approach using a rank order clustering. International Journal of Production Research 18(2): 213-232

[30] Chandrasekharan M P and Rajagopalan R 1986 MODROC an extension of rank order clustering for group technology. International Journal of Production Research 24(5): $1221-1233$

[31] Chandrasekharan M P and Rajagopalan R 1987 ZODIAC- an algorithm for concurrent formation of part-families and machine-cells. International Journal of Production Research 25(6): 835-850

[32] Jayakrishnan Nair G and Narendran T T 1998 CASE: A clustering algorithm for cell formation with sequence data. International Journal of Production Research 36(1): $157-180$

[33] Jayakrishnan Nair G and Narendran T T 1999 Accord: A bicriterion algorithm for cell formation using ordinal and ratiolevel data. International Journal of Production Research 37(3): 539-556

[34] Paydar M M, Iraj Mahdavi, Iman Sharafuddin and Maghsud Solimanpur 2010 Applying simulated annealing for designing cellular manufacturing systems using MDmTSPq. Computers and Industrial Engineering 59: 929-936

[35] Chang C-C, Wu, T-H and Wu C-W 2013 An efficient approach to determine cell formation, cell layout and intracellular machine sequence in cellular manufacturing systems. Computers and Industrial Engineering 66: 438-450

[36] Liu C, Wang J and Leung Joseph Y-T 2018 Integrated bacteria foraging algorithm for cellular manufacturing in supply chain considering facility transfer and production planning. Applied Soft Computing 62: 602-618

[37] Rabbani M, Farrokhi-Asl H and Ravanbakhsh M 2018 Dynamic cellular manufacturing system considering machine failure and workload balance, Journal of Industrial Engineering International, https://doi.org/10.1007/s40092-018-0261-y

[38] Soolaki M and Arkat J 2018 Incorporating dynamic cellular manufacturing into strategic supply chain design. International Journal of Advanced Manufacturing Technology
95(5-8): 2429-2447. https://doi.org/10.1007/s00170-0171346-2

[39] Solimanpur M and Elmi A 2013 A tabu search approach for cell scheduling problem with makespan criterion. International Journal of Production Economics 141: 639-645.

[40] Liang M and Zolfaghari S 1999 Machine cell formation considering processing times and machine capacities: An ortho-synapse Hopfield neural network approach. Journal of Intelligent Manufacturing 10: 437-447

[41] Vidal T, Teodor Gabriel Crainic, Michel Gendreau and Christian Prins 2013 Heuristics for multi-attribute vehicle routing problems: A survey and synthesis. European Journal of Operational Research 231: 1-21

[42] Mareda T, Gaudard L and Romerio F 2017 A Parametric Genetic Algorithm Approach to Assess Complementary Options of Large Scale Wind-solar Coupling. IEEE/CAA Journal of Automatica Sinica 4(2): 260-272

[43] Zolfaghari S and Liang M 2002 Comparative study of simulated annealing, genetic algorithms and tabu search for solving binary and comprehensive machine-grouping problems. International Journal of Production Research 40-9: 2141-2158

[44] Yuan H, Bi J, Tan W, Zhou M C, Li B H and Li J 2017 TTSA: An Effective Scheduling Approach for Delay Bounded Tasks in Hybrid Clouds. IEEE Transactions on Cybernetics 47(11): 3658-3668

[45] Moslemipour G 2018 A hybrid CS-SA intelligent approach to solve uncertain dynamic facility layout problems considering dependency of demands. Journal of Industrial Engineering International 14: 429. https://doi.org/10.1007/ s40092-017-0222-x

[46] Chibante R 2010 Simulated Annealing Theory with Applications published by Sciyo, Croatia

[47] Jawahar N, Aravindan P and Ponnambalam S G 1998 A genetic algorithm for scheduling flexible manufacturing systems. International Journal of Advanced Manufacturing Technology 14: 588-607

[48] Mak K L, Wong Y S and Wang X X 2000 An adaptive genetic algorithm for manufacturing cell formation. International Journal of Advanced Manufacturing Technology 16: 491-497

[49] James T L, Evelyn C Brown and Kellie B Keeling 2007 A hybrid grouping genetic algorithm for the cell formation problem. Computers and Operations Research 34: 2059-2079.

[50] Albadawi Z, Bashir H and Chen M 2005 A mathematical approach for the formation of manufacturing cells. Computers and Industrial Engineering 48: 3-21

[51] Harhalakis G, Ioannou G, Minis I and Nagi R 1994 Manufacturing cell formation under random product demand. International Journal of Production Research 32(1): 47-64 